\title{
Monomethylmercury sources in a tropical artificial reservoir
}

\author{
Bogdan Muresan ${ }^{a}$, Daniel Cossa ${ }^{a,}{ }^{*}$, Sandrine Richard ${ }^{b}$ and Yannick Dominique ${ }^{c}$
}

\author{
a Institut français de recherche pour l'exploitation durable de la mer (IFREMER), BP 21105, F.44311 Nantes \\ cedex 3, France \\ ${ }^{\mathrm{b}}$ HYDRECO, Laboratoire de Petit-Saut, BP 823, F.97388 Kourou, French Guiana \\ c Laboratoire d'écophysiologie et d'écotoxicologie des systèmes aquatiques (LEESA), CNRS 5805, F.33120 \\ Arcachon, France
}

*: Corresponding author : D. Cossa, Tel.: 3324037 41 76; email address : dcossa@ifremer.fr

\begin{abstract}
:
The distribution and speciation of mercury $(\mathrm{Hg})$ in the water column, the inputs (wet deposition and tributaries) and the outputs (atmospheric evasion and outlet) of an artificial partially anoxic tropical lake (Petit-Saut reservoir, French Guiana) were investigated on a seasonal basis in order to appraise the cycling and transformations of this metal. The total mercury $(\mathrm{HgT})$ concentrations in the oxygenated epilimnetic waters averaged $5 \pm 3 \mathrm{pmol} \mathrm{L}^{-1}$ in the unfiltered samples (HgTUNF) and $4 \pm 2 \mathrm{pmol} \mathrm{L}^{-1}$ in the dissolved (HgTD) phase $(<0.45 \mu \mathrm{m})$. On average, the monomethylmercury $(\mathrm{MMHg})$ constituted $8 \%, 40 \%$ and $18 \%$ of the $\mathrm{HgT}$ in the dissolved phase, the particulate suspended matter and in the unfiltered samples, respectively. Covariant elevated concentrations of particulate $\mathrm{MMHg}$ and chlorophyll $\mathrm{a}$ in the epilimnion suggest that phytoplankton is an active component for the $\mathrm{MMHg}$ transfer in the lake. In the anoxic hypolimnion the HgTUNF averages $13 \pm 6 \mathrm{pmol} \mathrm{L}^{-1}$ and the $\mathrm{HgTD} 8$ $\pm 4 \mathrm{pmol} \mathrm{L}^{-1}$. The averages of MMHgP and MMHgD in hypolimnetic waters were two and three times the corresponding values of the epilimnion, $170 \pm 90 \mathrm{pmol} \mathrm{g}^{-1}$ and $0.9 \pm 0.5 \mathrm{pmol} \mathrm{L}^{-1}$, respectively. In the long dry and wet seasons, at the flooded forest and upstream dam sampling stations, the vertical profiles of MMHgD concentrations accounted for two distinct maxima: one just below the oxycline and the other near the benthic interface. Direct wet atmospheric deposition accounted for 14 moles $\mathrm{yr}^{-1}$

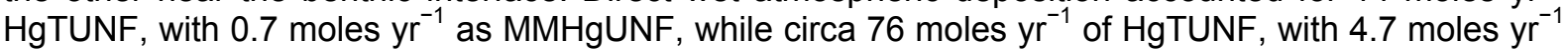
as MMHgUNF, coming from tributaries. Circa 78 moles (not, vert, similar $17 \%$ as $\mathrm{MMHg}$ ) are annually exported through the dam, while 23 moles $\mathrm{yr}^{-1}$ of $\mathrm{HgO}$ evolve in the atmosphere. A mass balance calculation suggests that the endogenic production of MMHgUNF attained 8.1 moles $\mathrm{yr}^{-1}$, corresponding to a methylation rate of $0.06 \% \mathrm{~d}^{-1}$. As a result, the Petit-Saut reservoir is a large manmade reactor that has extensively altered mercury speciation in favor of methylated species.
\end{abstract}

Keywords: Mercury; Methylmercury; Artificial reservoir; Tropical environment 


\section{Introduction}

The toxicological concerns regarding mercury $(\mathrm{Hg})$ has given rise to extensive studies regarding its distribution and speciation in freshwater environments. Special attention has been paid to monomethylmercury $(\mathrm{MMHg})$ because of its huge bioaccumulative capacity in aquatic food webs (e.g., up to $10^{7}$ according to Boudou et al., 2005) and toxicity (e.g., Zahir et al., 2005). If bacterial methylation of inorganic divalent $\mathrm{Hg}$ in low oxygen environments is reasonably recognised as being the main source of MMHg before its incorporation into food webs (e.g., Devereux et al., 1996; Benoit et al., 1999; King et al., 2001), identifying the various environments that the alkylation processes occurs in is a task that is still in progress. There has been much research into $\mathrm{Hg}$ speciation in temperate and cold regions and several meromictic and oligomictic lakes have been shown to assist in the build up of MMHg in their anoxic deep-water layers (e.g., Korthals and Winfrey, 1987; Cossa et al., 1994; Morrison and Watras, 1999). The redox (Eh) transition zone containing sulfate-reducing bacteria (SRB) has long been recognized as favoring microbial Hg methylation (e.g., Jensen and Jernelov, 1969; Gilmour et al., 1992; King et al., 1999; Mason and Lawrence, 1999; Benoit et al., 2003). Similar situations fostering $\mathrm{MMHg}$ formation have also been found in artificial lakes and a number of authors have even pointed out that filling hydroelectric reservoirs may result in increasing the $\mathrm{Hg}$ concentrations found in fish (e.g., Surma Aho et al., 1986; Verdon et al., 1991; Tremblay, 1996; Schetagne and Verdon, 1999). The methylating potential of equatorial or tropical lakes has been poorly explored to date and only a few studies on Hg speciation have focused on such areas (e.g., Guimares et al., $2000 \mathrm{a}$ and b; Roulet et al., 2000 and 2001; Coelho-Souza et al., 2006). However, Amazonian regions present a background of high $\mathrm{Hg}$ concentrations coupled to the active cycling of this metal. The natural ferralitic soil of Amazonia is rich in $\mathrm{Hg}$ (e.g., Roulet and Grimaldi, 2001; Roulet et al., 2001; Guedron et al., in press). In addition, the anthropogenic activities linked to gold mining are responsible for direct $\mathrm{Hg}$ introduction into the aquatic systems. Thus, the resulting elevated concentrations of inorganic $\mathrm{Hg}$ in the water column combined with active SRB (promoted by high temperature, high organic matter -OMand low dissolved oxygen) to favor $\mathrm{Hg}$ methylation. Consistently, high $\mathrm{MMHg}$ concentrations are expected in the vicinity of oxyclines in aquatic systems. These features have been recently demonstrated in the case of a man built lake in Petit-Saut, French Guiana (Coquery et al., 2003), where the flooding of more than $350 \mathrm{~km}^{2}$ of forest created an anoxic column of more than $20 \mathrm{~m}$ in depth. Furthermore, Durrieu et al. (2005) and Boudou et al. (2005) have described the $\mathrm{Hg}$ bioamplification in fish found in this system.

Here, we present data from this artificial tropical reservoir (Fig. 1) in order to identify sources and to quantify the probable formation of $\mathrm{MMHg}$ within the lake. These sources include the tributaries of the reservoir draining regions of active and former gold mining sites, the atmospheric deposition, the release from flooded forest, and the in situ production. For this purpose, we describe the $\mathrm{Hg}$ speciation in the water column during both the dry and wet season, and in the inputs and outputs of the system by a monitoring approach. The distributions of physical parameters (temperature, $\mathrm{pH}$, conductivity and turbulent diffusion) and major chemical species (dissolved oxygen, iron, sulfides, and OM) are used to try to create a comprehensive pattern of the $\mathrm{Hg}$ cycle in the system.

\section{Material and methods}

\subsection{Environmental settings}

The Petit-Saut hydroelectric reservoir (http://www.cg.ensmp.fr/Guyane/Compte _rendus/petit_sauthydreco.htm) is located in the tropical forest of French Guiana on the Sinnamary River basin (Fig. 1). The Sinnamary basin spans over $7000 \mathrm{~km}^{2}$ of crystalline rock formation overgrown by uninhabited primary forest (Richard, 1996). The Leblond, Coursibo and Tigre creeks are its main tributaries. The construction of the Petit-Saut hydroelectric dam started in 1989 and the flooding ended in 1995 with a resulting artificial lake stretching over $60 \mathrm{~km}$ in length and with a maximum width of $60 \mathrm{~km}$. During our sampling campaigns, the maximum water depth was $32 \mathrm{~m}$ (near station CR) and the surface area of the lake covered $230 \mathrm{~km}^{2}$. Total water volume, flooded surface area, and mean water depth were therefore estimated to be $3 \times 10^{9} \mathrm{~m}^{3}, 2.3 \times 10^{8} \mathrm{~m}^{2}$ and $13 \mathrm{~m}$, respectively. The annual mean discharge was measured downstream of the dam at $190 \mathrm{~m}^{3} \mathrm{~s}^{-1}$; from these figures a mean residence time of the water of approximately 6 months can be inferred.

The filling of the Petit-Saut hydroelectric reservoir sparked major modifications in the water chemistry of the former Sinnamary River. As the forest and fluvial ecosystem became a lacustrine environment 
thermal stratification occurred (Fig. 2). The waters of the reservoir rapidly stratified with an oxygenated epilimnion and an anoxic hypolimnion (Richard, 1996). The degradation of immerged OM, combined with the mixing of water masses and light limitation, governs the vertical distribution of aquatic substances within the stratified water-body. Reduced substances such as methane and hydrogen sulfide are distributed along a marked vertical concentration gradient in the vicinity of the oxycline (Dumestre et al., 1999). In comparison with the epilimnion, the hypolimnion exhibited elevated concentrations of reduced elements. According to Richard (1996), the main processes responsible for water enrichment were OM degradation (ammonium, phosphates, humic acids, etc.) and mobilization from the geological substratum (iron, manganese, silica, etc.).

\subsection{Sample collection}

\subsubsection{Rain sampling}

Wet deposition was collected from April 2003 to December 2004 at the HYDRECO field laboratory station, $200 \mathrm{~m}$ away from the dam (Fig. 1). Samples for the amount of rainfall, conductivity, $\mathrm{pH}$ and occasionally total organic carbon (TOC) determinations were collected in polyethylene bags. The rain collectors for $\mathrm{Hg}$ samples consisted of a $500 \mathrm{~mL}$ acid-clean Teflon (FEP) bottle attached to a $14 \mathrm{~cm}$ diameter Teflon (PTFE) funnel. A Teflon net $(76 \mu \mathrm{m}$ pore size, Savillex) was added to the bottom of the funnel in order to avoid the introduction of large particles into the collection bottle. A $16 \mathrm{~cm}$ long flute of Teflon (PTFE) allowed rainwater to be collected directly from the base of the funnel to the bottom of the bottle. Bottles were capped, double bagged, then frozen at $-18^{\circ} \mathrm{C}$ and kept in the dark until analysis. Precipitation waters were analyzed for (i) total $\mathrm{Hg}$ in unfiltered samples ( $\mathrm{HgT}_{\mathrm{UNF}}$ ), (ii) reactive $\mathrm{Hg}$ in unfiltered samples ( $\mathrm{HgR}_{\mathrm{UNF}}$ ), and (iii) monomethylmercury in unfiltered samples (MMHgunf). The subscripts $\mathrm{D}$ and $\mathrm{P}$ are used further down in the text to denote samples filtered through $0.45 \mu \mathrm{m}\left(\mathrm{LCR}^{\circledR}\right.$ membranes, Millipore) and particulate matter retained on the membrane respectively. Note that $\mathrm{HgR}$ is the easily reducible $\mathrm{Hg}$ fraction obtained by direct reduction with $\mathrm{SnCl}_{2}$, i.e., a proxy of the inorganic and the labile organic fractions of $\mathrm{Hg}^{\prime \prime}$.

\subsubsection{Water column sampling}

Samples from the reservoir were collected during three sampling campaigns of approximately two months that took place in March-April 2003 (the short dry season), January-February 2004 (the short wet season) and May-June 2004 (the long wet season). These were designated as Matoutou 1, 2 and 3 respectively. For each campaign, the water column was sampled at the same three stations: the flooded forest (FF), the center of the reservoir (CR) and $200 \mathrm{~m}$ upstream of the dam (UD) (Fig. 1). Sampling stations were chosen in order to suitably describe the temporal and spatial variability of the biogeochemical and physical processes that affect $\mathrm{Hg}$ speciation. Station FF is comprised of a cove that does not exceed $17 \mathrm{~m}$ in depth $\left(4^{\circ} 55.67^{\prime} \mathrm{N}-52^{\circ} 59.96^{\prime} \mathrm{W}\right)$. Except for the riverbed, macrophyte (trees, shrubs) immerged vegetation covered more than $90 \%$ of the surface of the reservoir before flooding. Station CR, located in the middle of the former Sinnamary riverbed, is comprised of the main lake body of the Petit-Saut reservoir $\left(4^{\circ} 56.382^{\prime} \mathrm{N}-53^{\circ} 02.610^{\prime} \mathrm{W}\right)$. The water column usually exceeds $20 \mathrm{~m}$ in depth and displays a sharp and permanent stratification. Lastly, Station UD provided $\mathrm{Hg}$ distribution and speciation in some of the most altered masses of water from the reservoir $\left(5^{\circ} 03.77^{\prime} \mathrm{N}\right.$ $\left.53^{\circ} 02.45^{\prime} \mathrm{W}\right)$. The ultra clean sampling techniques and analytical methods applied for water analyses are those described and discussed in detail by Bloom (1989) and Cossa et al. (2002 and 2003). In short, water column samples were collected using a peristaltic pump and acid-cleaned polypropylene tubing. Polyethylene gloves were used for handling operations. Samples were collected in acid-clean Teflon (FEP) bottles. Water filtrations were performed through $0.45 \mu \mathrm{m}$ membranes (LCR ${ }^{\circledR}$, Millipore) and the water samples stored in a similar manner as the rain samples. Analyses of $\mathrm{HgT}_{\mathrm{UNF}}, \mathrm{Hg}_{\mathrm{D}}$ and reactive fractions were processed within 24 hours after collection, while DGM were performed within 2 hours. Aliquots of both filtered and unfiltered water samples for MMHg determinations were acidified to $0.5 \%$ $(\mathrm{v} / \mathrm{v})$ with $\mathrm{HCl}$ (Suprapur ${ }^{\circledR}$, Merck). Filters with particles were stored in Petri dishes at $-18^{\circ} \mathrm{C}$ and kept in dark until analysis.

\subsubsection{Tributaries and tailrace sampling}

From March 2003 to December 2004, Hg exportations downstream of the dam had been monitored on a weekly basis. Samples were collected a few meters downstream of the outflow of the turbines (Station CS, Fig. 1). As the turbines are fed with water from the hypolimnion, the samples, at Station 
CS, accounted for the exported water flow from the anoxic part of the reservoir. The CS site precedes an aeration system set up in order to increase the dissolved oxygen concentration in water. Regarding water inputs to the artificial lake, upstream tributaries (Sinnamary, Coursibo and Leblond streams) were sampled in December 2004 and March 2005.

\subsubsection{Sediments sampling}

Within the reservoir water-body, the decomposition of submerged vegetation followed slow degradation kinetics. Ten years after the impoundment completion, dead tree trunks still emerging from water provide little access to the sediment. However, using a peristaltic pump and a polyethylene-tubing put on the bottom, we collected floc materials (i.e. accumulated slurries) that deposited at the sediment-water interface (SWI) from the FF, CR and UD stations. In addition, two sediment cores (noted \# 1 and \# 2) were collected for $\mathrm{HgT}_{\mathrm{p}}$ analysis upstream of the Sinnamary River (Fig.1). Core \#1 originated from the Saut Dalles station (SD), $11 \mathrm{~km}$ upstream and ahead of the reservoir entrance, while core \#2 was collected further down the Takari Tanté fall (200 $\mathrm{m}$ inside the reservoir itself). Sediment cores were sampled by hand using Plexiglas tubes then transported in coolers back to the field laboratory. The same day, horizontal sectioning was performed at a centimetric resolution using a polypropylene knife. Sediment slices were immediately placed into 50 $\mathrm{mL}$ acid-cleaned polycarbonate tubes, capped, frozen at $-20^{\circ} \mathrm{C}$ in dark conditions, and then freezedried before $\mathrm{HgT}_{\mathrm{p}}$ analyses.

\subsection{Sample analyses}

\subsubsection{Ancillary parameters}

Temperature, $\mathrm{pH}$, dissolved oxygen, conductivity and redox were recorded in situ with a YSI 600XLM multiparameter probe. Total sulfides $\left(\Sigma \mathrm{H}_{2} \mathrm{~S}\right)$ and "dissolved" $(<0.45 \mu \mathrm{m})$ iron $\left(\mathrm{FeT}_{\mathrm{D}}\right)$ were measured by colorimetry (Merck, 2001). Samples for Chlorophylla (Chla) determination were collected on $0.7 \mu \mathrm{m}$ (Whatman, GF/C) glass filters and determined according to Ameel et al. (1998).

\subsubsection{Mercury speciation}

All Hg species in water samples were detected by cold vapor atomic fluorescence spectrometry (AFS). HgT was determined according to Bloom and Fitzgerald (1988), by the formation of volatile elemental $\mathrm{Hg}$ (released by $\mathrm{SnCl}_{2}$ reduction, after 30 minutes of acidic $\mathrm{BrCl}$ oxidation) and its preconcentration on a gold column. The detailed procedure is provided by Cossa et al. (2003). HgR was obtained by direct reduction with $\mathrm{SnCl}_{2}$. The analysis of DGM on unfiltered water samples were carried out within 2 hours of collection. The suspended particulate matter (SPM) samples collected by filtration on - pre-weighed $\mathrm{LCR}^{\circledR}$ membranes were first digested with concentrated $\mathrm{HCl}^{\circledR} \mathrm{HNO}_{3}(1 / 9, \mathrm{v} / \mathrm{v})$ in Teflon (PFA) reactors ( $80{ }^{\circ} \mathrm{C}$; 4 hours) prior to $\mathrm{HgT}_{\mathrm{P}}$ determinations using an automated atomic absorption spectrometer (AMA-254 ${ }^{\circledR}$, Altec). This technique comprises a calcination of the freeze-dried samples under an oxygen gas stream in order to produce elemental $\mathrm{Hg}$ vapor and its subsequent amalgamation on a gold trap; Hg vapor subsequently being measured by AAS (Cossa et al., 2002). The detection limits, defined as 3.3 times the standard deviation of the blanks, amounted to $0.1 \mathrm{pmol} \mathrm{L}{ }^{-1}$ and $0.035 \mathrm{nmol} \cdot \mathrm{g}^{-1}$ for the $\mathrm{HgT}_{\mathrm{D}}$ and $\mathrm{HgT}_{\mathrm{P}}$ respectively. The corresponding reproducibilities (the coefficient of variation of five replicate samples) were less than $10 \%$. The accuracy for $\mathrm{Hg}$ determinations in solids was regularly checked using a certified reference material (MESS-3) obtained from the National Council of Canada. Loss on ignition (LOI) was determined as a proxy for organic matter content by measuring the weight loss on lyophilized sediment after 24 hours at $450^{\circ} \mathrm{C}$. MMHg was determined using the method initially proposed by Bloom (1989) and modified by Liang et al. (1994) and Leermarkers et al. (2001). MMHgunF and $\mathrm{MMHg}_{\mathrm{D}}$ in acidified water were extracted by $\mathrm{CH}_{2} \mathrm{Cl}_{2}$ and then transferred into Milli-Q ${ }^{\circledR}$ water by evaporating the organic solvent. The aqueous solutions were analyzed for $\mathrm{MMHg}$ by gas chromatography after ethylation and adsorption/desorption on a Tenax ${ }^{\circledR}$ column. For MMHg, a 3 hour acidic dissolution $\left(\mathrm{HNO}_{3} 65 \%\right)$ of the filtered SPM took place before the extraction procedure described previously. Detection limits were $0.05 \mathrm{pmol} \mathrm{L} \mathrm{L}^{-1}$ and $0.005 \mathrm{pmol} \cdot \mathrm{g}^{-1}$ for respectively a $20 \mathrm{~mL}$ water and $200 \mathrm{mg}$ solid sample. Reproducibilities were less than $15 \%$ for all $\mathrm{MMHg}$ analyses. Using the available certified reference material (IAEA-405), the accuracy of the method was estimated to be more than $5 \%$ with $91 \pm 8 \%$ recovery. The detailed procedure is given by Cossa et al. (2002). 


\subsection{Modeling the turbulent diffusion}

The applied turbulent diffusion model is the one descibed by Peretyazhko et al. (2005). $\mathrm{MMHg}_{\mathrm{D}}$ and $\mathrm{HgT}_{\mathrm{D}}$ turbulent fluxes are formulated at the SWI and water column chemocline (WCC) as the product of a vertical turbulent diffusion coefficient $\mathrm{K}_{\mathrm{z}}\left(\mathrm{m}^{2} \mathrm{~s}^{-1}\right)$, and the concentration gradient:

$\mathfrak{I}=-\mathrm{K}_{\mathrm{z}}(\partial \mathrm{C} / \partial \mathrm{z})$

Eddy diffusivities are estimated on wind speed data and temperature profiles. In the well-mixed surface layer, turbulence is assumed to be wind driven and $\mathrm{K}_{\mathrm{z}}$ is estimated by:

$$
K_{z}=\gamma_{\text {mix }}\left(\frac{\rho_{\text {air }} C_{10}}{\rho}\right)^{3 / 2} \frac{\stackrel{3}{\varpi}_{10}}{N^{2} \mathrm{kz}} \quad N=\left(-\frac{g}{\rho} \frac{\partial \rho}{\partial z}\right)^{1 / 2}
$$

where $\gamma_{\text {mix }}$ is the non-dimensional mixing efficiency (close to 0.2; Peltier and Caulfield, 2003), $\varpi_{10}$ is the wind speed at $10 \mathrm{~m}$ altitude (about $3 \mathrm{~m} \mathrm{~s}^{-1}$ ), $\mathrm{C}_{10}$ is the wind-stress coefficient (approximately $10^{-3}$ for $\left.\varpi_{10}<7 \mathrm{~m} \mathrm{~s}^{-1}\right), \mathrm{k}=0.4$ is the Karman constant, $\mathrm{z}$ is the depth $(\mathrm{m}), \rho$ and $\rho_{\text {air }}$ are the densities of water and air, respectively. Temperature is used as a conservative tracer in order to determine the mixing profile from below the well-mixed surface layer:

$\mathrm{K}_{\mathrm{z}}(\partial \mathrm{T} / \partial \mathrm{z})=\mathrm{K}_{\mathrm{zo}}(\partial \mathrm{T} / \partial \mathrm{z})_{\mathrm{z} 0}$

where $T$ is the temperature, $(\partial T / \partial z)$ is the temperature gradient and $z 0$ is the depth of the lower boundary of the well-mixed epilimnion (4 to $10 \mathrm{~m}$ ).

\section{Results and Discussion}

\subsection{Chemical characteristics of the waters}

Figures $2 \mathrm{~A}$ to $2 \mathrm{C}$ show the vertical profiles for temperature, suspended particulate matter (SPM), conductivity, $\mathrm{pH}$, dissolved oxygen, iron $\left(\mathrm{FeT}_{\mathrm{D}}\right)$ and sulphide $\left(\Sigma \mathrm{H}_{2} \mathrm{~S}\right)$ obtained during our three main campaigns in March-April 2003, January-February 2004 and May-June 2004, at the three stations (FF, $\mathrm{CR}$ and $\mathrm{UD}$ ). The temperature of the reservoir ranged between 25 and $30{ }^{\circ} \mathrm{C}$. Depending on the season and site, the thermocline was located between 5 and $10 \mathrm{~m}$ in depth. The main feature in the distribution of SPM was a peak of concentration at the thermocline and/or near the bottom. The conductivity measurements displayed a strong time dependency with high values occurring during the short dry season and lower ones by the end of the long wet season. Vertical profiles of conductivity usually increased with depth displaying a sharp gradient close to the thermocline that increased the stability of the water column. The $\mathrm{pH}$ was slightly acidic in the epilimnion (6.1 \pm 0.3 units) and acidic in the hypolimnion ( $5.6 \pm 0.5$ units), as a result of the geological composition of soils and the organic acids from the OM decomposition. In addition, elevated precipitation rates (close to $3000 \mathrm{~mm} \mathrm{yr}^{-1}$ ) of acid rains (4.6 $\pm 0.4 \mathrm{pH}$ units in 2003/04) tend to accentuate the alteration phenomena in the region of the reservoir maintaining the $\mathrm{pH}$ below neutrality.

The vertical distributions of dissolved oxygen showed a correlation with thermal stratification. Oxygen concentrations were usually close to saturation with values approaching $0.2 \mathrm{mmol} \mathrm{L}^{-1}$ towards the surface. Except for occasional advection processes and/or the in-depth injection of epilimnic water, usually observed during the long wet season, the anoxic condition prevailed further down the hypolimnion. Consistently, the $\Sigma \mathrm{H}_{2} \mathrm{~S}$ concentrations were below the detection limit $\left(<0.1 \mu \mathrm{mol} \mathrm{L^{-1 }}\right)$ within the epilimnion, and displayed a marked gradient under the oxycline. $\mathrm{FeT}_{\mathrm{D}}$ concentrations in the epilimnion were generally low $\left(<1 \mu \mathrm{mol} \mathrm{L}^{-1}\right)$, while they average averaged $30 \pm 20 \mu \mathrm{mol} \mathrm{L}^{-1}$ in the hypolimnion. $\mathrm{FeT}_{\mathrm{D}}$ concentrations displayed a broad seasonal variability: the short (February 2004) and long (June 2004) wet seasons displayed concentrations of $27 \pm 17 \mu \mathrm{mol} \mathrm{L}^{-1}$ and $14 \pm 16 \mu \mathrm{mol} \mathrm{L}^{-1}$ respectively, and the maximum value of $38 \pm 11 \mu \mathrm{mol} \mathrm{L^{-1 }}$ was recorded during the short dry season (April 2003). The dry season corresponded to a phase of accumulation for reduced chemical compounds in the water column, while the wet season defined a period of occasional dilution of the hypolimnion by surface waters. Heavily laden with iron (laterite), the soil reacts with hydrogen sulfide causing the appearance of iron sulfide complexes (including colloids measured with the filtered fraction, $<0.45 \mu \mathrm{m})$, suggested by the correlation between $\Sigma \mathrm{H}_{2} \mathrm{~S}$ and $\mathrm{FeT}_{\mathrm{D}}\left(\mathrm{r}^{2}=0.73\right)$. In addition, $\Sigma \mathrm{H}_{2} \mathrm{~S}$ and $\mathrm{FeT}_{\mathrm{D}}$ exhibited analog temporal trends, i.e., hypolimnetic concentrations of sulfides at 
Station CR ranged from $3.6 \pm 0.8 \mu \mathrm{mol} \mathrm{L}^{-1}$ to $1.2 \pm 1.1$ and $0.2 \pm 0.1 \mu \mathrm{mol} \mathrm{L}^{-1}$ starting with short dry season then short wet and finally long wet seasons. According to Dumestre et al. (1999), the sulfur gradient was always superimposed on a sharp peak of bacterial abundance. Albeit a minority, sulfatereducing bacteria (SRB) were preferentially found just below the oxic-anoxic interface (Dumestre et al., 2001). A small but active fraction of the green sulfur bacteria were closely associated with the sulfatereducing population. Thus, a loop between sulfide producing and sulfide consuming bacteria was established in the reservoir.

\section{2. $\mathrm{Hg}$ in the water column}

As expected from the physico-chemical characteristics, the vertical profiles of $\mathrm{Hg}$ species in the water column demonstrated a considerable discontinuity between the epi and hypolimnion. Apart from DGM and $\mathrm{HgR}_{\mathrm{UNF}}$, the highest concentrations of all the $\mathrm{Hg}$ species were generally located in the hypolimnion of the reservoir (Table 1, Fig. 3A to $3 \mathrm{C}$ ). Such a pattern was particularly marked for HgT UNF and $\mathrm{MMHg}_{\mathrm{D}}$, which is three times more enriched in the deep compartment compared with the surface layer. Reported results were consistent with earlier observations made by Coquery et al. (2003) in the course of the first MMHg survey measurements in the reservoir. In addition, the operationally defined $\mathrm{HgR}_{\text {UNF }}$ was more than $50 \%$ of DGM, which implies that the labile inorganic divalent $\mathrm{Hg}$ species were at very low concentrations. The corollary is that most of the $\mathrm{Hg}^{\prime \prime}$ seemed strongly bound to organic carbon and/or sulfur.

\subsubsection{The epilimnion}

$\mathrm{HgT}$ in the epilimnion was mainly present in the dissolved $(<0.45 \mu \mathrm{m})$ fraction $\left(74 \pm 4 \%\right.$ of $\left.\mathrm{HgT}_{\mathrm{UNF}}\right)$, while for $\mathrm{MMHg}$ the particulate form dominated $\left(60 \pm 20 \%\right.$ as $\left.\mathrm{MMHg}_{\mathrm{P}}\right)$. The maximum concentration of $\mathrm{HgT}_{\mathrm{UNF}}$ occurred in either the short or - long wet seasons $\left(6.0 \pm 1.4\right.$ and $5.1 \pm 1.6 \mathrm{pmol} \mathrm{L}^{-1}$ respectively) depending on sampled study sites. During the short dry season, HgTunF averaged $3.9 \pm$ $0.8 \mathrm{pmol} \mathrm{L}^{-1}$. The $\mathrm{HgT}_{\mathrm{D}}$ concentrations increase with depth (Fig. 3) suggesting that the hypolimnetic waters may contribute to the build up of the epilimnetic $\mathrm{HgT}_{\mathrm{D}}$. This process is clearly visible during the long wet season (Fig. 3A) when the destratification of the water column occurs, as illustrated by the conductivity profile (Fig; $2 \mathrm{~A}$ ). Regarding the particulate fraction, epilimnetic $\operatorname{HgT}_{\mathrm{P}}$ displayed an inverse relationship when plotted as a function of SPM $\left(\left[\mathrm{HgT}_{\mathrm{P}}\right]_{\mathrm{pmol} \mathrm{g}-1}=800 /[\mathrm{SPM}]_{\mathrm{mg} \mathrm{L}-1} ; \mathrm{r}^{2}=0.50 ; \mathrm{p}<0.05\right)$. While SPM increased in the epilimnion up to $10 \mathrm{mg} \mathrm{L}^{-1}, \mathrm{HgT}_{\mathrm{P}}$ decreased down to $100 \mathrm{pmol} \mathrm{g}^{-1}$ (FF and UD, February 2004). The low Hg content epilimnic particles (down to $120 \pm 100 \mathrm{pmol} \mathrm{g}^{-1}$ ) were observed during the short wet season when SPM concentrations in water were high $\left(14 \pm 3 \mathrm{mg} \mathrm{L}^{-1}\right)$ due to intense erosion during the flood. Since eroded particles from the tributaries banks and beds, delivered during flood events, were poor in $\mathrm{Hg}$ (Peretyazhko, 2002), a dilution of the $\mathrm{Hg}$ rich epilimnetic SPM by eroded particles may explain the decrease in the overall $\mathrm{HgT}_{\mathrm{P}}$ concentrations during the high runoff periods. The concurrent increase of the $\mathrm{HgT}_{\mathrm{D}}$ levels during the short wet season also contributed to the marked lowering of the $\mathrm{Hg}$ partition coefficient $\left(\mathrm{Kd}_{\mathrm{Hg}}=\mathrm{HgT}_{\mathrm{P}} / \mathrm{HgT}_{\mathrm{D}}\right)$ with the increase of the SPM concentration $\left(\log \mathrm{Kd}_{\mathrm{Hg}}=-0.07[\mathrm{SPM}]_{\mathrm{mg} \mathrm{L}-1}+5.3 ; \mathrm{r}^{2}=0.38 ; \mathrm{p}<0.05\right)$. Such a relationship suggested that a significant fraction of eroded particles may be composed by readily labile colloids which contribute to the so-called "dissolved" phase (Schuster, 1991; Lee and Iverfeldt, 1991; Hurley et al., 1995).

In the epilimnion, concentrations of methylated $\mathrm{Hg}$ species measured in this study were quite similar to those measured during water stratification at the Caballo reservoir in New Mexico (Canavan et al. 2000). The maxima of $\mathrm{MMHg}_{\mathrm{D}}\left(0.4 \pm 0.2 \mathrm{pmol} \mathrm{L}^{-1}\right)$ and $\mathrm{MMHg}_{\mathrm{P}}\left(180 \pm 70 \mathrm{pmol} \mathrm{g}{ }^{-1}\right)$ occurred in the short dry season (Fig. $3 \mathrm{~A}$ to $3 \mathrm{C}$ ), when primary production and development of the phototrophic bacterial community were high (Dumestre et al., 1999). Indeed, a significant positive relationship between the chlorophylla and $\mathrm{MMHg}_{\mathrm{P}}$ concentrations in the water $\left(\left[\mathrm{MMHg}_{\mathrm{P}}\right]_{\mathrm{pmol} L-1}=510^{-3}[\mathrm{Chla}]_{\mu g} \mathrm{~L}-1+\right.$ $\left.510^{-2} ; r^{2}=0.44 ; p<0.05\right)$ was observed. In addition, Chla and $\mathrm{MMHg}_{\mathrm{p}}$ increased with depth from 16 to $32 \mathrm{\mu g} \mathrm{L}^{-1}$ and from 0.12 to $0.20 \mathrm{pmol} \mathrm{L}^{-1}$, respectively. This suggests that phytoplankton not only concentrated $\mathrm{MMHg}$ from waters, but also that the microbial activity related to phytoplankton degradation at this oxycline favor $\mathrm{Hg}$ methylation. In the wet season, the decrease in water column stratification and subsequent mixing between hypolimnetic and epilimnetic bacterial guilds should limit the phototrophic driven methylation mechanisms. This phenomenon may be accentuated by the common decrease in light exposure (increase in cloudiness cover) and water residence time within the reservoir (from 4 to 9 months). This interpretation is consistent with the lowest $\mathrm{MMHg}_{\mathrm{D}}(0.2 \pm 0.1 \mathrm{pmol}$ $\left.\mathrm{L}^{-1}\right)$ and $\mathrm{MMHg}_{\mathrm{P}}\left(35 \pm 15 \mathrm{pmol} \mathrm{g}^{-1}\right)$ levels determined during the short wet season. The spatial 
variability of $\mathrm{Hg}$ concentration in the epilimnion was considered by comparing average concentrations at the three stations (CR, UD and FF, Table 1) using $t$-tests. No statistically significant differences were found between the mean concentrations at the three stations regardless of the $\mathrm{Hg}$ species considered.

\subsubsection{The hypolimnion}

The $\mathrm{HgT}_{\mathrm{UNF}}, \mathrm{MMHg}_{\mathrm{UNF}}, \mathrm{HgT}_{\mathrm{D}}$ and $\mathrm{MMHg}_{\mathrm{D}}$ mean concentrations were twice as high in the hypolimnion compared to the epilimnion (Table 1, Fig. $3 \mathrm{~A}$ to $3 \mathrm{C}$ ). The highest $\mathrm{HgT}_{\mathrm{UNF}}\left(17 \pm 5 \mathrm{pmol} \mathrm{L}^{-1}\right)$ and $\mathrm{HgT}_{\mathrm{D}}$ $\left(10 \pm 4 \mathrm{pmol} \mathrm{L}^{-1}\right)$ concentrations were measured during the intense runoff episode that occurred during the short wet season. These results agree with previous observations by Peretyazhko et al. (2005). The short wet season gathers high SPM levels $\left(8 \pm 3 \mathrm{mg} \mathrm{L}^{-1}\right)$ and $\mathrm{Hg}$ contents $\left(600 \pm 350 \mathrm{pmol} \mathrm{g}^{-1}\right)$ of hypolimnetic particles, thus contributing to increase the mercury concentration associated with suspended solids $\left(8 \pm 3 \mathrm{pmol} \mathrm{L}^{-1}\right)$. On the contrary, the short dry season contains the lowest $\mathrm{Hg}$ concentrations $\left(3 \pm 2 \mathrm{pmol} \mathrm{L}^{-1}\right)$ in the particulate phase due to a low Hg content in the SPM $(250 \pm 200$ pmol g ${ }^{-1}$ ).

With a mean concentration of $0.9 \pm 0.5 \mathrm{pmol} \mathrm{L}^{-1}$ (Table 1), the contribution of $\mathrm{MMHg}_{\mathrm{D}}$ to the $\mathrm{HgT}_{\mathrm{D}}$ stood at $16 \pm 6 \%$. While no significant trend was observed at Station FF, stations located in the vicinity of the former Sinnamary riverbed (CR and UD), showed a substantial increase in $\mathrm{MMHg}_{\mathrm{D}}$ concentrations during the long wet season (Fig. 4). During this period, $\mathrm{MMHg}_{\mathrm{D}}$ at Station $\mathrm{CR}$ averaged $1.8 \pm 1.0 \mathrm{pmol} \mathrm{L}^{-1}$ for a $26 \mathrm{~m}$ deep hypolimnetic water column (Table 1). Vertical profiles of both $\mathrm{MMHg}_{\mathrm{D}}$ and $\mathrm{MMHg}_{\mathrm{P}}$ concentrations accounted for a bimodal distribution (Fig. 3A to 3C), with two distinct maxima, one close to the WCC and the other to the SWI. MMHg $\mathrm{D}_{\mathrm{D}}$ concentrations at the WCC and the SWI respectively attained $2.8 \mathrm{pmol} \mathrm{L}^{-1}$ (CR, June 2004) and $5.9 \mathrm{pmol} \mathrm{L}^{-1}$ (CR, April 2003) corresponding to a $\mathrm{MMHg}_{\mathrm{D}} / \mathrm{HgT}_{\mathrm{D}}$ ratio close to one. These high $\mathrm{MMHg}_{\mathrm{D}}$ concentrations highlighted the role of the WCC and SWI as potential sites for $\mathrm{Hg}$ methylation and/or MMHg remobilization. From the acquired profiles (Fig. 2 and 3 ) and using the turbulent diffusion model, described earlier, it was possible to assess the total amount of $\mathrm{MMHg}_{\mathrm{D}}$ that originated from WCC and SWI to about 7 moles $\mathrm{yr}^{-}$ 1. Vertical profiles of hypolimnetic $\mathrm{MMHg}_{\mathrm{p}}$ followed that of particulate inorganic carbon (CPI unpublished results from Hydreco laboratory) $\left(\left[\mathrm{MMHg}_{\mathrm{P}}\right]_{\mathrm{pmol} g-1}=25[\mathrm{CPI}]_{\mathrm{mmol} \mathrm{g-1}}+90 ; \mathrm{r}^{2}=0.59 ; \mathrm{p}<\right.$ $0.05)$, a proxy for the organic matter degradation in the hypolimnion. During the dry season, several authors showed an intense OM mineralization and bacterial activity in the vicinity of the WCC (Dumestre et al., 1999-2001; Horeau 1999).

Overall, the vertical distributions of the $\mathrm{Hg}$ species were characterized by high levels in the hypolimnion and relatively wide variations with seasons. In addition, $\mathrm{MMHg}$ concentrations both in the dissolved and particulate phases were enriched in the hypolimnion and peaked at the WCC and SWI, which respectively represent suboxic and anoxic zones where OM is actively recycled.

\subsubsection{Epi-hypolimnion exchanges}

As already noticed by various authors (e.g., Peretyazhko, 2002), the vertical stratification of the reservoir was seasonally affected due to intense rainfalls and peaked riverine inputs. Observed differences in conductivity, temperature and dissolved oxygen between wet and dry seasons were mainly due to the strong precipitations and the incursions of water between warm epilimnic waters and colder hypolimnetic waters (Fig. 2A to $2 \mathrm{C}$ ). As a result, the turbulent diffusion flux of hypolimnetic $\mathrm{HgT}_{\mathrm{D}}$ that entered the epilimnion increased from the dry to the wet season. During the dry season (April 2003), the mean flux of $\mathrm{HgT}_{\mathrm{D}}$ was oriented towards the hypolimnion $\left(200 \pm 100 \mathrm{pmol} \mathrm{m} \mathrm{m}^{-2} \cdot \mathrm{d}^{-1}\right)$. Later, in the short wet season (February 2004), the $\mathrm{HgT}_{\mathrm{D}}$ flux depicted a broad turn round towards the epilimnion $\left(330 \pm 100 \mathrm{pmol} \mathrm{m} \mathrm{m}^{-2} \cdot \mathrm{d}^{-1}\right)$. In the course of the long wet season (June 2004), as the mixing regime weakened the water column stratification, the flux of $\mathrm{HgT}_{\mathrm{D}}$ remained directed towards the epilimnion with a mean value of $250 \pm 50 \mathrm{pmol} \mathrm{m}{ }^{-2} \cdot \mathrm{d}^{-1}$. Annual fluxes of $\mathrm{HgT}_{\mathrm{D}}$ and $\mathrm{MMHg}_{\mathrm{D}}$ from the hypolimnion to the epilimnion were estimated to be 45 and $25 \mathrm{nmol} \mathrm{m} \cdot \mathrm{m}^{-2} \cdot \mathrm{y}^{-1}$. A comparative study between the oxycline and the SWI revealed that the equivalent of 40 and $70 \%$ of the apparent annual sediment efflux of $\mathrm{HgT}_{\mathrm{D}}$ and $\mathrm{MMHg}_{\mathrm{D}}$ were respectively transported to the epilimnion. Maxima of epilimnetic $\mathrm{MMHg}_{\mathrm{D}}$ (up to $0.5 \mathrm{pmol} \mathrm{L}^{-1}$ ) were generally recorded in the dry season at $3 \mathrm{~m}$ in depth. This depth corresponds to a layer of high chlorophyll abundance (up to $20 \mu \mathrm{g} \mathrm{L}^{-1}$ ) which accounts for more than $80 \%$ of total pigments (Dumestre et al., 2001; De Junet, 2004). 


\section{3. $\mathrm{Hg}$ in the sediments}

Little is still known about the sedimentary processes in the Petit-Saut reservoir. Thus, we consider the main allochthonous and autochthonous sources of sedimentary particles. The first group is from riverine sources and consists of detrital material and eroded soils carried in during flood events and among sediments within the mouths of the creeks flowing to the reservoir, and autochthonous sources are of planktonic origin (De Junet, 2004). In the former riverbed (CR and UD sites), the mean $\mathrm{HgT}_{\mathrm{P}}$ concentrations of SWI slurries and particles from the moored traps were $1100 \pm 400$ and $1800 \pm 130$ pmol g ${ }^{-1}$, respectively (Table 2 and Fig. 5). Mean concentrations of SWI slurries were lower (400 \pm 250 pmol g ${ }^{-1}$ ) near the shorelines (Table 2, FF Station). Considering the sedimenting methylated fraction of $\mathrm{HgT}_{\mathrm{p}}$, accumulated slurries exhibited higher $\mathrm{MMHg}_{\mathrm{p}}$ levels than particles from the moored traps (17 \pm 5 vs $5 \pm 3 \%$ of $\mathrm{HgT}_{\mathrm{P}}$ ). This suggests a net SWI $\mathrm{Hg}$ methylation and its export from the sediment.

\subsubsection{Particulate $\mathrm{Hg}$ flux to the sediments}

Sediment traps were deployed over a period of 6 weeks in November-December 2003 (dry season) at Station CR. According to De Junet (2004), particulate vertical transport in the water column originated from endemic plankton and it is mainly composed of chlorophyceae $(>90 \%)$, chlorobiaceae $(<10 \%)$ and a lesser fraction of biofilm coupled to terrestrial OM. The sedimentary fluxes were estimated using the following relation:

$$
\text { Flux }=\frac{\Delta \mathrm{m}}{\mathrm{S} \cdot \Delta \mathrm{t}}
$$

with $\Delta \mathrm{m}$ mass of accumulated material, $\mathrm{S}$ section of the collection cone $\left(0.13 \mathrm{~m}^{2}\right)$ and $\Delta \mathrm{t}$ sampling period. The deposition fluxes were thus estimated to be 160,90 and $165 \mathrm{mg} \mathrm{m}^{-2} \mathrm{~d}^{-1}$ at 7,20 and 30 (near bottom) $\mathrm{m}$ in depth respectively, suggesting particle dissolution or zooplanktontic grazing between the epilimnion layer and $20 \mathrm{~m}$, and particulate formation or resuspension near the bottom. Because of the likely resuspension events recorded in the fluxes, it is probable that the real $\operatorname{HgT}_{p}$ and $\mathrm{MMHg}_{\mathrm{p}}$ deposition fluxes correspond to an intermediate situation between those estimates at a depth of 20 and $30 \mathrm{~m}$. Thus, from the deposition fluxes and $\mathrm{Hg}$ content of particles, it is possible to calculate the November-December 2003 particulate $\mathrm{Hg}$ deposition to be $59-297 \mathrm{pmol} \mathrm{m}^{-2} \mathrm{~d}^{-1}$. Assuming a constant annual flux, annual deposition should then vary between $22-105 \mathrm{nmol} \mathrm{m}^{-2} \mathrm{yr}^{-1}$. Applied to the entire surface of the reservoir (close to $2.3 \times 10^{8} \mathrm{~m}^{2}$ ), circa 5-24 moles of $\mathrm{Hg}$ bounded to the particulate phase, reached the SWI. Methylated Hg represented an average of $5 \pm 3 \%$ of this amount, with a maximum value of $10 \%$.

\subsubsection{Effluxes of dissolved $\mathrm{Hg}$ out of the sediment}

According to Peretyazhko et al. (2005), the main flux of dissolved $\mathrm{Hg}$ to the hypolimnion originated from both degradation of flooded vegetation and partial dissolution of ferralitic soils. In fact, the flooding of these types of soils leads to a reductive dissolution of $\mathrm{Fe}$ oxyhydroxides $\left(\mathrm{Fe}_{\mathrm{Ox}}\right)$ and a migration of the released $\mathrm{Hg}$ into the aquatic ecosystem (Roulet et al., 1998b). As a result of the permanent sedimentary $\mathrm{Hg}$ efflux, observed profiles of $\mathrm{Hg}_{\mathrm{D}}$ and $\mathrm{MMHg}_{\mathrm{D}}$ usually displayed higher concentrations at the SWI (Fig. $3 \mathrm{~A}$ to $3 \mathrm{C}$ ). Turbulent fluxes of $\mathrm{HgT}_{\mathrm{D}}$ and $\mathrm{MMHg}_{\mathrm{D}}$ at the $\mathrm{SWI}$, formulated as the product of the vertical turbulent diffusion coefficient and the mean concentration gradient within the first meter above the sediments, were estimated to be $120-650$ and $50-400 \mathrm{pmol} \mathrm{m}^{-}$ ${ }_{2} \mathrm{~d}^{-1}$, respectively. The corresponding annual effluxes were $100 \pm 90$ and $32 \pm 20 \mathrm{nmol} \mathrm{m}^{-2} \mathrm{yr}^{-1}$, respectively. Regarding the SWI fluxes, the annual sedimentary efflux $\left(100 \pm 90 \mathrm{nmol} \mathrm{m}^{-2} \mathrm{yr}^{-1}\right)$ and the particulate deposition $\left(60 \pm 50 \mathrm{nmol} \mathrm{m}^{-2} \mathrm{yr}^{-1}\right)$ of $\mathrm{HgT}_{\mathrm{p}}$ were comparable. Nevertheless, the methylated percentage was substantially higher in the dissolved fraction outgoing from the sediments (about 30 $\%$ ) than in the particulate fraction incoming to the SWI (around $5 \%$ ). Such a discrepancy suggests (i) that sediments are a major source of $\mathrm{MMHg}_{\mathrm{D}}$ to the water column coupled to (ii) a substantial mobility of methylated species at the SWI that could limit its sedimentary accumulation. These estimates are however based on momentum situations, and an intrusion of surface waters, as shown by the conductivity, dissolved oxygen and $\Sigma \mathrm{H}_{2} \mathrm{~S}$ vertical profiles (Fig. 2B), could have led to the dilution of 
$\mathrm{Hg}_{\mathrm{D}}$ and $\mathrm{MMHg}_{\mathrm{D}}$ near bottom concentrations and thus increase the respective concentration gradients (Fig. 3B).

Because of the relative isolation from the former riverbed, relevant effluxes of $\mathrm{HgT}_{D}$ and $\mathrm{MMHg}_{\mathrm{D}}$ were determined at Station FF. These were 190, 100 and $200 \mathrm{pmol} \mathrm{m}^{-2} \mathrm{~d}^{-1}$ for $\mathrm{HgT}_{\mathrm{D}}$ in the short dry, short wet and long wet seasons respectively. For the same periods $\mathrm{MMHg}_{\mathrm{D}}$ effluxes were 50,30 and 60 pmol m $\mathrm{m}^{-2} \mathrm{~d}^{-1}$. With an average of $60 \pm 20$ and $16 \pm 5 \mathrm{nmol} \mathrm{m}^{-2} \mathrm{yr}^{-1}$ respectively, the annual effluxes of $\mathrm{HgT}_{\mathrm{D}}$ and $\mathrm{MMHg}_{\mathrm{D}}$ at Station FF amounted to about $50 \%$ less than mean "apparent" effluxes calculated at Stations CR and UD. Seasonal variations of $\mathrm{HgT}_{\mathrm{D}}$ and $\mathrm{MMHg}_{\mathrm{D}}$ effluxes covaried with those of $\mathrm{FeT}_{\mathrm{D}}\left(3,0.2\right.$ and $8 \mathrm{mmol} \mathrm{m}^{-2} \mathrm{~d}^{-1}$ in that order). This suggests that the reductive dissolution of iron contributed to the mobilization of dissolved $\mathrm{Hg}$ species at the SWI. On the other hand, the positive relationship between $\mathrm{Hg}$ content of particles (respectively 140, 550 and $2100 \mathrm{pmol} \mathrm{g}^{-1}$ ) and $\Sigma \mathrm{H}_{2} \mathrm{~S}$ effluxes (orderly $0.05,0.09$ and $0.14 \mathrm{mmol} \mathrm{m}^{-2} \mathrm{~d}^{-1}$ ) in bottom waters suggests that mobilized $\mathrm{HgT}_{\mathrm{D}}$ is rapidly recycled onto the particulate phase through precipitation as cinnabar or iron sulfide trapping processes. Since $\mathrm{MMHg}_{\mathrm{D}}$ effluxes exhibited a similar development to $\mathrm{MMHg}$ in superficial sediments (respectively 130, 60 and $70 \mathrm{pmol} \mathrm{g}^{-1}$ ), we hypothesized that a notable fraction of mobilized $\mathrm{MMHg}_{\mathrm{D}}$ may be composed of colloids. On the other hand, divergences between $\mathrm{MMHg}_{\mathrm{p}}$ and $\mathrm{\Sigma H}_{2} \mathrm{~S}$ effluxes make it possible to surmise that either (i) $\mathrm{MMHg}_{\mathrm{D}}$ colloids are more composed of degraded OM than sulfide ligands or (ii) that increased $\Sigma \mathrm{H}_{2} \mathrm{~S}$ effluxes result in lowered $\mathrm{Hg}$ availability for methylation as noticed by others (Benoit et al., 2001 and 2003).

\section{4. $3 \mathrm{Hg}$ exchanges at boundaries}

\subsubsection{Inputs by rain}

In the vicinity of the reservoir, $\mathrm{Hg}$ concentrations in rain were representative of unimpacted North Atlantic environments (Lamborg et al., 1999). Indeed, HgT UNF concentrations averaged $16 \pm 12$ pmol $\mathrm{L}^{-1}$ (Table 1). The temporal distribution of $\mathrm{HgT}_{\mathrm{UNF}}$ (Fig. 6) exhibited a pattern of high concentrations during the late dry season (up to $57.5 \mathrm{pmol} \mathrm{L}^{-1}$ in November 2004) and low concentrations in the course of the wet season (down to $2.7 \mathrm{pmol} \mathrm{L}^{-1}$ in March 2004). Besides $\mathrm{HgT}_{\mathrm{UNF}}$, the speciation of $\mathrm{Hg}$ was investigated through $\mathrm{HgR}_{\mathrm{UNF}}$, and $\mathrm{MMHg}_{\mathrm{UNF}}$ analysis. Approximately $20 \%$ of the $\mathrm{HgT}_{\mathrm{UNF}}$ was composed by HgR reactive mercury (a proxy of the inorganic and labile organic fractions of $\mathrm{Hg}^{\prime \prime}$ ). With concentrations varying from 0.1 to $20.8 \mathrm{pmol} \mathrm{L}^{-1}$, its temporal distribution revealed a positive correlation with $\mathrm{HgT}_{\mathrm{UNF}}\left(\mathrm{r}^{2}=0.54 ; \mathrm{p}<0.05\right)$. Regarding $\mathrm{MMHg}_{\mathrm{UNF}}$, concentrations varied widely from 0.05 to $10.2 \mathrm{pmol} \mathrm{L}^{-1}$ with a mean value of $0.80 \mathrm{pmol} \mathrm{L}^{-1}$.

When coupling the $3 \mathrm{~m}$ of annual precipitation rate of the 2003-2004 period to $\mathrm{Hg}$ concentrations in rain one can estimate the annual wet deposition to the reservoir. Thus, $\mathrm{HgT}_{\mathrm{UNF}}, \mathrm{HgR}_{\mathrm{UNF}}$ and MMHg $\mathrm{MNF}_{\mathrm{U} F}$ bulk wet deposition averaged respectively $46 \pm 35,9 \pm 11$ and $3 \pm 5 \mathrm{nmol} \mathrm{m}^{-2} \mathrm{yr}^{-1}$. With the notable exception of $\mathrm{MMHg}_{\mathrm{UNF}}$, wet deposition corresponded to the low range of data found in the literature (e.g., Mason et al., 1997, 1999). On the other hand, $\mathrm{Pb}^{210}$ and $\mathrm{Hg}$ analysis in air, rain and atmosphere (http://lgge.ujf-grenoble.fr/publiscience/rapports/activite-2001.pdf) provided access to the total atmospheric deposition of $\mathrm{Hg}$ within the reservoir area. This was estimated to be $60 \mathrm{nmol} \mathrm{m}^{-2} \mathrm{yr}^{-1}$. The computed value was consistent with those reported by Lacerda et al. (1999) for the whole Amazonian basin $\left(40-60 \mathrm{nmol} \mathrm{m}^{-2} \mathrm{yr}^{-1}\right)$. An additional rough estimation of total atmospheric $\mathrm{Hg}$ deposition was provided using $\mathrm{Pb}^{210}$ data of $\mathrm{HgT}_{\mathrm{P}}$ sedimentary profiles (Barriel et al., 2001). The obtained result was in the same order of magnitude $\left(150-200 \mathrm{nmol} \mathrm{m}^{-2} \mathrm{yr}^{-1}\right)$. With $46 \mathrm{nmol} \mathrm{m} \mathrm{yr}^{-1}$, wet atmospheric deposition corresponded to approximately $75 \%$ of total atmospheric deposition of $\mathrm{Hg}^{\prime} 60 \mathrm{nmol} \mathrm{m}^{-2} \mathrm{yr}^{-}$ ${ }^{1}$ ). This result demonstrated that rainfall was an efficient pathway for atmospheric $\mathrm{Hg}$ to reach the reservoir (21 moles $\left.\mathrm{yr}^{-1}\right)$.

\subsubsection{Inputs from tributaries}

In December 2004 and March 2005, main water inputs to the reservoir (the Sinnamary River and the Coursibo, Leblond creeks) were sampled and analyzed for $\mathrm{HgT}_{\mathrm{D}}$ and $\mathrm{MMHg}_{\mathrm{D}}$ (Table 3). These data constituted the first $\mathrm{Hg}$ measurements for the upstream of the Sinnamary River (Saut-Dalles). Except for the high $\mathrm{HgT}_{\mathrm{D}}$ levels recorded during the 1999 dry season into the Leblond creek (Fig. 7), the recently measured $\mathrm{HgT}_{\mathrm{D}}$ and $\mathrm{MMHg}_{\mathrm{D}}$ concentrations were comparable to previous surveys (Coquery et al., 2003). Based on measured concentration ranges and a mean water discharge of $190 \mathrm{~m}^{3} \mathrm{~s}^{-1}$ for the 2003/04 period, we estimated the range within which the annual $\mathrm{Hg}$ inputs to the reservoir should be 45-105 and 1-4 moles for $\mathrm{HgT}_{\mathrm{D}}$ and $\mathrm{MMHg}_{\mathrm{D}}$, respectively. At the mouth of the tributaries, the percentages of $\mathrm{HgT}_{\mathrm{UNF}}$ and $\mathrm{MMHg}_{\mathrm{UNF}}$ associated with the particulate phase was 41 and $25 \%$ 
respectively. However, most of the particles and the associated $\mathrm{Hg}$ settle near the entrances of the reservoir as shown by the SPM distribution (Fig. 7). As a result, once into the water-body of the reservoir, the epilimnetic percentage of $\mathrm{HgT}_{\mathrm{UNF}}$ associated with the particulate phase decreased to 25 $\pm 15 \%$.

\subsubsection{Tailrace exportations}

The HgT UNF concentrations at Station CS varied between 3.8 pmol L $^{-1}$ (June 2003) and $27.9 \mathrm{pmol} \mathrm{L}^{-1}$ (July 2004) (Fig. 8). The average concentration of $\mathrm{HgT}_{\mathrm{UNF}}$ was $13 \pm 5 \mathrm{pmol} \mathrm{L}^{-1}$. According to measurements performed on the filtered samples, about $60 \%\left(8 \pm 2 \mathrm{pmol} \mathrm{L}^{-1}\right)$ of the $\mathrm{Hg}$ outflowing the reservoir was composed of $\mathrm{HgT}_{\mathrm{D}}$. In comparison, similar concentrations were measured in the hypolimnion of the reservoir at a depth of between 8 and $15 \mathrm{~m}$. In spite of the relative uniformity of $\mathrm{HgT}_{\text {UNF }}$ concentrations, a seasonal pattern was apparent through semi-annual cycles. For instance, we observed a tendency towards elevated concentrations at the beginning and in the middle of the dry season (March to April then August to November). In contrast, the wet seasons displayed the lowest measured values (May to July then December to February). This pattern was in agreement with the general hypothesis that reduced species concentrated inside the hypolimnion during the dry season and were diluted in the course of the wet season. The relative homogeneity of $\mathrm{Hg}_{\mathrm{UNF}}$ and $\mathrm{HgT}_{\mathrm{D}}$ concentrations between the upstream (9-16 pmol L-1 of the reservoir tributaries) and downstream (13 $\pm 5 \mathrm{pmol} \mathrm{L}^{-1}$ ) of the reservoir would account for the reduced amplitude of these cycles (about $10 \mathrm{pmol}$ $\mathrm{L}^{-1}$ ).

The dam $\mathrm{Hg}$ exportation fluxes have been calculated (Table 4) using the weekly water discharges and weekly $\mathrm{Hg}$ concentrations. These significantly followed $\mathrm{Hg}$ concentrations in the tailrace water $\left(\mathrm{r}^{2}=\right.$ $0.40 ; \mathrm{p}<0.05)$. Such a relationship suggests that hypolimnetic processes may extensively affect $\mathrm{Hg}$ levels downstream of the dam. For total $\mathrm{Hg}$, the estimations are similar whatever the annual period being considered (March 2003 to March 2004 or October 2003 to September 2004). Yet, as for concentrations, exportation fluxes exhibited a significant variability with seasons (Fig. 8). Except for the intense runoff episodes (peaks of exportation), HgT UNF outputs were $25 \%$ higher during the dry seasons than in the course of the wet seasons (6.4 vs 4.7 moles month $\left.{ }^{-1}\right)$. Two distinct mechanisms can be cited: (i) transport [the 4-5 month interval between the wet seasons maximal water inputs and the dry seasons elevated $\mathrm{HgT}_{\mathrm{UNF}}$ discharges equals the residence time of water into the system] and (ii) in situ production or mobilization [the dry season depict the overall hypolimnetic water loading with reduced compounds (Section 3.3.5.)]. With regards to the methylated species, MMHgunf levels in the dam-expelled waters exhibited a maximum of concentrations $\left(8.4 \mathrm{pmol} \mathrm{L}^{-1}\right)$ and of exportation fluxes $\left(0.15\right.$ moles $\left.^{-1}\right)$ during the late wet season (Fig. 8). This period characterizes the confluence of elevated amounts of water leaving the reservoir (around $200 \mathrm{~m}^{3} \mathrm{~s}^{-1}$ ) and relatively high MMHgunF levels in its hypolimnion (close to $4 \mathrm{pmol} \mathrm{L}{ }^{-1}$ ). Except for isolated Station $\mathrm{FF}, \mathrm{HgT}_{\mathrm{D}}$ and $\mathrm{MMHg}_{\mathrm{D}}$ presented similar developments in the hypolimnion of the reservoir and discharged waters (Fig. 4). However, long term processes (exceeding the annual scale) or episodic events (such as extreme particle discharge or water column destabilization) may also account for these variations.

\subsection{Hg reduction and methylation in the water column}

The Regional Bureau for Industry, Research and Environment (DRIRE), estimated that 200 to 300 tons of $\mathrm{Hg}$ have been disseminated into the environment in French Guiana since 1850 (Richard et al., 2002). The local discharge of elemental $\mathrm{Hg}$ to the Petit-Saut reservoir originates principally from the upstream gold-mining area of Saint Elie. The amount of anthropogenically discharged $\mathrm{Hg}$ since the last century was evaluated to approximately 37 tons (Petot, 1993). However, in the course of our study and except for the intense runoff events (mainly in wet seasons), the signature of the upstream $\mathrm{Hg}$ contamination rapidly diminished at a given distance from the gold-mining area (Fig. 7). This phenomenon was presumably related to a broad dilution of impacted waters while entering the artificial lake and/or to the rapid sedimentation of particulate fraction of $\mathrm{Hg}\left(90 \%\right.$ of the $\left.\mathrm{HgT}_{\mathrm{UNF}}\right)$ in the upstream area of the reservoir. In 10 years of flooding, $\mathrm{Hg}$ inputs to the Petit-Saut reservoir were estimated to be circa 8000 moles (i.e. 1.6 tons $\mathrm{Hg}$ ). The dominant fraction corresponds to the originally flooded vegetation and soils (60 and $20 \%$ respectively). Atmospheric, riverine and sedimentary source approaches $15 \%$ of $\mathrm{Hg}$ inputs. Local discharge from the upstream gold-mining area of Saint Elie was estimated to be less than $5 \%$ of the total. Thus, it appears that, at the time of our sampling, most of the $\mathrm{Hg}$ introduced into the Petit-Saut reservoir was from natural sources including leaching and erosion of the drainage basin and atmospheric deposition. 
Once inside the epilimnion of the reservoir, $\mathrm{Hg}$ can either be eliminated towards the atmosphere after photochemical reduction (Xiao et al., 1995; Amyot et al., 1997b), transferred to the hypolimnion after adsorption on SPM, and undergo further transformations such as methylation or (co)precipitation (e.g., with Fe species). As proposed by Beucher et al. (2002) the high DGM concentrations and its sursaturation in the surface water of the reservoir suggests the photochemical production of $\mathrm{Hg}^{0}$ in the presence of a reductive agent such as organic matter and especially iron-carboxylated ionic ligands. As described in a companion paper (Muresan et al., 2007), the partial evasion of $\mathrm{Hg}$ at the AWI (20.7 moles $\mathrm{yr}^{-1}$ ) was twice as high as the mean wet deposition of $\mathrm{HgT}_{\mathrm{UNF}}\left(10.6\right.$ moles $\left.\mathrm{yr}^{-1}\right)$.

A preliminary budget can be built up for MMHg in the Petit-Saut reservoir using the measurements in the main water sources. The most striking conclusion concerning the 2003-2004 period was that dam exportations averaged 13.5 moles $\mathrm{yr}^{-1}$ although a maximum of 5.4 moles $\mathrm{yr}^{-1}$ of $\mathrm{MMHg}_{\mathrm{unF}}$ reached the Petit-Saut artificial lake via rain and upstream tributaries. Despite the uncertainty surrounding these figures, there is a strong suggestion that a large quantity of $\mathrm{MMHg}$ was produced in the reservoir itself. Referring to the 76 moles $\mathrm{yr}^{-1}$ of $\mathrm{HgT}_{\text {UNF }}$ passing through the artificial lake, the endogenic production of MMHgunF attained $0.06 \% \mathrm{~d}^{-1}$. The build up of $\mathrm{MMHg}$ in the epilimnion of the Petit-Saut reservoir was obvious from the $\mathrm{MMHg}_{\mathrm{p}}$ increase from $2.3 \pm 0.3$ to $40 \pm 30 \%$ of the $\mathrm{HgT}_{\mathrm{p}}$ (i.e. $25 \pm 15$ to $80 \pm 70$ $\mathrm{pmol} \mathrm{g}^{-1}$ ) between the upstream of the Sinnamary River and the epilimnion of the reservoir. Maxima of $\mathrm{MMHg}_{\mathrm{p}}$ were measured circa $3 \mathrm{~m}$ below the reservoir AWI (Fig. 3A to 3C). Despite the evidence of a transfer of dissolved methylated $\mathrm{Hg}$ from the hypolimnion, the marked logKd $\mathrm{MMHg}_{\mathrm{H}}$ increase between tributaries $(4.6 \pm 0.2)$ and epilimnetic $(5.5 \pm 0.1)$ waters supports $\mathrm{Hg}$ methylation in the SPM of the reservoir. Indeed, Coelho-Souza et al. (2006) concluded from incubation experiments that different heterotrophic microorganisms associated with tropical freshwater phytoplankton may play a role in $\mathrm{Hg}$ methylation.

As shown by Roulet et al. (1998a) and Peretyazhko et al. (2005), the erosion of the fine particles from the pedological horizon prompted an increase in $\mathrm{Hg}$ effluxes into the aquatic environment principally in wet seasons. The concentration and speciation of $\mathrm{Hg}$ bound to particles that reached the hypolimnion of the reservoir actually displayed a high seasonal variability. In the dry season, the strong stratification between epi/hypolimnion as well as the intense degradation of the OM would have contributed to accumulating $\mathrm{MMHg}\left(180 \pm 130 \mathrm{pmol} \mathrm{g}^{-1}\right)$ on an endogenic, strongly mineralized and $\mathrm{Hg}$-impoverished particulate substratum $\left(250 \pm 200 \mathrm{pmol} \mathrm{g}^{-1}\right)$. Conversely, in the wet season, the weak stratification between epi/hypolimnion, as well as the increasing of particulate discharges to the reservoir (the wash out of Hg-enriched particles, $4300 \pm 2000 \mathrm{pmol} \mathrm{g}^{-1}$ ), would have contributed to reducing the recycling of OM and consequently the methylated fraction in SPM (110 $\left.\pm 80 \mathrm{pmol} \mathrm{g}^{-1}\right)$. Furthermore, the relative acidity of hypolimnetic waters $(5.6 \pm 0.5 \mathrm{pH}$ units) combined with the intense microbial reduction of $\mathrm{Fe}_{\mathrm{Ox}}$ that prevail beyond a depth of $6 \mathrm{~m}$ (Peretyazhko et al., 2005) support the idea of a progressive mobilization (desorption) of $\mathrm{Hg}$ from sedimenting particles. This assumption is supported by the gradual decrease in the $\mathrm{Hg}$ partition coefficient with $\mathrm{SPM}\left(\log \mathrm{Kd}_{\mathrm{Hg}}=-0.06[\mathrm{SPM}]_{\mathrm{mgL}-1}\right.$ $\left.+5.5 ; r^{2}=0.42 ; p<0.05\right)$.

The high $\mathrm{MMHg}_{\mathrm{D}}$ concentrations measured in the hypolimnion of the reservoir $\left(0.9 \pm 0.5 \mathrm{pmol} \mathrm{L}^{-1}\right)$ are consistent with the presence of low pH and Eh, which according to Compeau and Bartha (1985) and Gilmour and Henry (1991), not only help to increase methylation rates but also to decrease demethylation rates. Furthermore, during the wet seasons, $\mathrm{MMHg}_{\mathrm{D}}$ concentrations displayed a high variability depending the sampling stations (Fig. 3), with the highest concentrations in the reservoir corresponded to the stations close to the former Sinnamary riverbed $\left(1.5 \pm 0.8 \mathrm{pmol} \mathrm{L}^{-1}\right)$. According to Dumestre et al. (1997), the in-depth injection of surface water that occurs during the wet seasons helps to stimulate the SRB activity through the injection and/or formation of sulfates in a suboxic milieu. When plotted against $\Sigma \mathrm{H}_{2} \mathrm{~S}$, the dissolved methylated fraction $\left(\mathrm{MMHg}_{\mathrm{D}} / \mathrm{Hg}_{\mathrm{D}}\right.$; a proxy of in situ methylation (Benoit et al. 2001) exhibited a maximum of around $0.3 \mu \mathrm{mol} \mathrm{L}^{-1} \Sigma \mathrm{H}_{2} \mathrm{~S}$ (Fig. 9), which suggests that an optimum sulfide concentration favors $\mathrm{Hg}$ methylation. This observation is consistent with the hypothesis of neutral $\mathrm{Hg}$-S complexes controlling the bioavailability of inorganic $\mathrm{Hg}$ for SRB methylation (Benoit et al., 2001 and 2003). During dry seasons, high $\mathrm{MMHg}_{\mathrm{D}}$ concentrations were observed at the SWI around $4 \mu \mathrm{mol} \mathrm{L}^{-1} \Sigma \mathrm{H}_{2} \mathrm{~S}$ (Fig. 9). These values are proportional to the MMHg effluxes from sediment calculated in section 3.3.2 $\left(\left[\mathrm{MMHg}_{\mathrm{D}}\right]_{\mathrm{pmol} \mathrm{L}-1}(\mathrm{SWI})=0.02 \mathfrak{I}_{\mathrm{MMHgD}}(\mathrm{SWI})_{\mathrm{pmol} \mathrm{m}-2 \mathrm{~d}-1}+\right.$ $\left.0.15 ; r^{2}=0.74 ; p<0.05\right)$. In summary, these observations strongly suggest that the $\mathrm{MMHg}_{\mathrm{D}}$ built up in the Petit-Saut reservoir, at the former Sinnamary riverbed, were governed (i) in the wet seasons, by the in situ methylation of $\mathrm{Hg}$ due to enhanced SRB activity and, (ii) in the dry season, by the MMHg mobilization from the sediments (Fig 3B). 


\subsection{Hg mobilization at the SWI}

According to Roulet et al. (1999), the anthropogenic contribution from gold-mining sources accounts for $3 \%$ of the overall content of $\mathrm{Hg}$ in Amazonian soils. Hence, $\mathrm{Hg}$ would have been principally accumulated through natural pedologic processes. Ferralitic soils are widespread in the area of the Petit-Saut reservoir. The inundation of such soil, usually leads to the rapid establishment of reducing conditions through the entire soil profile and results in a net loss of $25-40 \%$ of the initial $\mathrm{Fe}_{\mathrm{Ox}}$ (Vizier, 1978; Gunnison et al., 1985). As oxygen deficiency favors the reductive dissolution of $\mathrm{Fe}_{\mathrm{Ox}}$, it subsequently may strongly enhance the mobilization of $\mathrm{Hg}$ at the SWI. Apart from those, the anoxic condition that usually prevailed at the SWI supports the absence of an oxic barrier limiting the release of $\mathrm{Hg}$ from sediments (Bothner et al., 1980). A diffusion of complexed $\mathrm{Hg}$ towards the water column was therefore likely. For instance, the annual turbulent efflux of $\mathrm{FeT}_{\mathrm{D}}$ at the SWI of the FF station averaged $1.3 \pm 1.0 \mathrm{~mol} \mathrm{~m}^{-2} \mathrm{yr}^{-1}$. Such a high value accounted for the substantial remobilization of $\mathrm{Fe}$ in the reservoir ten years after the impoundment completion. According to Roulet and Lucotte (1995), $\mathrm{Fe}_{\mathrm{Ox}}$ are fairly abundant in ferralitic soils even after ten years of inundation (300-500 $\mu \mathrm{mol} \mathrm{g}{ }^{-1}$ which correspond to 20 tons ha ${ }^{-1}$ ). The reductive dissolution mechanisms thus allowed nearly $20 \%$ of the initially Fe-bounded $\mathrm{Hg}$ (estimated to $7 \mathrm{~g} \mathrm{ha}^{-1}$ ) to escape from the ferralitic soil matrix. With circa $1.2 \mathrm{~g}$ ha ${ }^{-1}$ of $\mathrm{Hg}$ (i.e. $60 \pm 20 \mathrm{nmol} \mathrm{m}^{-2} \mathrm{yr}^{-1}$ ), the cumulated effluxes of $\mathrm{HgT}_{\mathrm{D}}$ at Station FF confirmed this trend.

Apart from iron, depth distribution of $\mathrm{HgT}_{\mathrm{P}}$ and LOI in core \#1 and \#2 suggested that $\mathrm{Hg}$ was also affected by OM content (Fig. 5). The acidic conditions that prevailed in the hypolimnion (5.6 $\pm 0.5 \mathrm{pH}$ units) as well as the elevated organic content of sediments (close to $20 \%$ ) supported the hypothesis of a potential leaching of free humic substances at the SWI. As a matter of fact, in Core \#2, the simultaneous increase with depth in $\mathrm{HgT}_{\mathrm{P}}\left(200-1100 \mathrm{pmol} \mathrm{g}^{-1}\right)$ and LOI (6-27 \%) pointed to the concomitant mobilization of humic substances and $\mathrm{Hg}$ due to upward migration. This pattern was not observed in Core \#1 neither for $\mathrm{HgT}_{\mathrm{P}}$ nor LOI. The differentiation between both profiles probably resulted from the change in sedimentation rate between the upstream of the Sinnamary River (Core $\# 1$ ) and the Petit-Saut artificial lake (Core \#2). If we admit that average $\mathrm{HgT}_{\mathrm{p}}$ concentration in Core \#1 was representative of local impregnation by $\mathrm{Hg}\left(730 \pm 70 \mathrm{pmol} \mathrm{g}^{-1}\right)$, the remobilization of OM permitted about $30 \%$ of complexed $\mathrm{Hg}$ to escape the flooded soils. It is worthwhile noting that the given estimation is only representative of an order of magnitude given that sharp differences in both OM content and water chemistry may occur within the reservoir.

The warm temperatures, anaerobic conditions and elevated organic content measured at the SWI defined suitable conditions for production and/or mobilization of $\mathrm{MMHg}$. Despite $\mathrm{MMHg}_{\mathrm{P}}$ concentrations being low in ferralitic soils (around $1 \%$ of $\mathrm{HgT}_{\mathrm{p}}$; Roulet and Lucotte, 1995), high levels of $\mathrm{MMHg}_{\mathrm{D}}$ were measured in the deepest part of the water column (Fig. 9). In fact, rapid recycling of endogenous and/or deposited OM may act as a potential source of MMHg in the vicinity of the SWI ten years after the impounding completion. Compared to the average concentration of the hypolimnion $\left(0.9 \pm 0.5 \mathrm{pmol} \mathrm{L}^{-1}\right)$, mean concentration of $\mathrm{MMHg}_{\mathrm{D}}$ at the SWI was significantly higher $(1.4 \pm 0.5 \mathrm{pmol}$ $\mathrm{L}^{-1}$ ). Using turbulent diffusion at Station $\mathrm{FF}$, the corresponding annual efflux of $\mathrm{MMHg}_{\mathrm{D}}$ at the SWI was estimated to be $16 \pm 5 \mathrm{nmol} \mathrm{m}^{-2} \mathrm{yr}^{-1}$. This value roughly represented $30 \%$ of the $\mathrm{HgT}_{\mathrm{D}}$ exported by inundated soils. On the other hand, it was possible to observe that the gradual enrichment of epibenthic waters in $\mathrm{MMHg}_{\mathrm{D}}$ occurred with the decrease of $\mathrm{MMHg}_{\mathrm{P}}$ in SPM. This trend was confirmed by lower values of $\mathrm{MMHg}$ partition coefficient $\left(\operatorname{logKd}_{\mathrm{MMHg}} ; 4.9 \pm 0.2\right.$ vs $5.6 \pm 0.5$ ) and $\mathrm{MMHg}_{\mathrm{P}}$ concentrations $\left(130 \pm 40\right.$ vs $\left.300 \pm 100 \mathrm{pmol} \mathrm{g}^{-1}\right)$ at the SWI than a few meters above. It is thus likely that the reductive dissolution and/or partial desorption of $\mathrm{Hg}$ enriched SPM may also have participated in levelling up the epibenthic $\mathrm{MMHg}_{\mathrm{D}}$ concentrations. For instance, elevated logKd $\mathrm{MMHg}_{\mathrm{M}}$ values were determined within the low conductivity layer that usually developed in the wet season due to the indepth injection of surface water.

\section{Summary and Conclusions}

Identified sources of $\mathrm{Hg}$ to the Petit-Saut reservoir consist of atmospheric deposition, tributaries and flooded soils (neglecting groundwaters). Atmospheric deposition accounted for circa 14 moles $\mathrm{yr}^{-1} \mathrm{Hg}$ of which approximately $75 \%$ (11 moles $\mathrm{yr}^{-1}$ ) originated from rainfall. Atmospheric deposition accounted for around $18 \%$ of the minimum HgTuNF input via local tributaries $\left(\sim 76\right.$ moles $\left.\mathrm{yr}^{-1}\right)$. Remnant degradation of flooded vegetation and partial dissolution of ferralitic soils seemingly release 
14 moles $\mathrm{yr}^{-1} \mathrm{HgT}_{\mathrm{D}}$ into the hypolimnetic waters. The exports of $\mathrm{Hg}$ from the Petit-Saut reservoir include the atmospheric volatilization, the dam water discharges; the sink is via particles sedimentation. Atmospheric volatilization at the air-water interface represented circa 21 moles $\mathrm{yr}^{-1}$ of $\mathrm{Hg}^{0}$ (Muresan et al, 2007), which is 1.5 times the HgT UNF rainfall deposition. The outflow of $\mathrm{HgT}_{\text {UNF }}$ through the Petit-Saut dam (around 78 moles $\mathrm{yr}^{-1}$ ) appears to be equilibrated with the upstream riverine inputs. At the SWI the particulate bounded $\mathrm{Hg}$ deposition (14.6 moles $\mathrm{yr}^{-1}$ ) was roughly equilibrated with the calculated effluxes $\left(13.8\right.$ moles $\left.\mathrm{yr}^{-1}\right)$. This suggested that the reservoir did not significantly affect the overall $\mathrm{HgT}_{\text {UNF }}$ concentrations in the whole Sinnamary system (Fig. 10).

Sources of $\mathrm{MMHg}$ at the Petit-Saut reservoir correspond to those of $\mathrm{HgT}$ with an extra contribution of the water column chemocline. As for $\mathrm{HgT}_{\mathrm{UNF}}$, MMHg $\mathrm{UNF}_{\mathrm{NF}}$ was primarily imported by local tributaries (close to 4.7 moles $\mathrm{yr}^{-1}$ ). Comparatively, the atmospheric MMHgunF deposition was

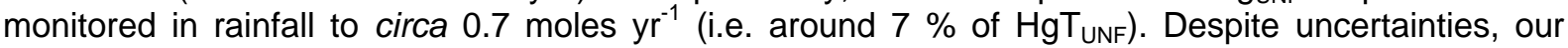
results strongly suggest that a large quantity of MMHg was produced in the reservoir itself. Sharp concentration gradients and high methylated percentages, proxies for net methylation, depicted the WCC and SWI. The cumulative net endogenous production of $\mathrm{MMHg}_{\mathrm{D}}$ for those particular sites reached 7.3 moles $\mathrm{yr}^{-1}$. Identified sinks of $\mathrm{MMHg}$ in the Petit-Saut reservoir are the particle sedimentation and the dam water discharges. These respectively accounted for 0.7 (as $\mathrm{MMHg}_{\mathrm{P}}$ ) and 13.5 (as $\mathrm{MMHg}_{\mathrm{uNF}}$ ) moles $\mathrm{yr}^{-1}$. The poor contribution of the particulate pump seemingly originated from the reductive conditions that prevailed at the SWI: dissolution and/or partial desorption of the MMHg enriched particles. Unlike $\mathrm{HgT}$, with sinks locally equilibrated with sources, broad discrepancies were observed in the $\mathrm{MMHg}$ balance. As a result most of the endogenically generated $\mathrm{MMHg}$ (the dominant source for the system) was exported from the reservoir, downstream of the dam.

During the 2003-2004 period, whereas a maximum of 5.4 moles $\mathrm{yr}^{-1} \mathrm{MMHg}$ unF reached the Petit-Saut reservoir via rainfall and tributaries, dam exportations averaged 13.5 moles $\mathrm{yr}^{-1}$. Referring to the 76 moles $\mathrm{yr}^{-1}$ of $\mathrm{HgT}_{\mathrm{UNF}}$ passing through the artificial lake, the in situ net production of MMHguNF averaged $0.06 \% \mathrm{~d}^{-1}$. Following a similar approach, the in situ net production of $\mathrm{MMHg}_{\mathrm{D}}$ attained 0.11 $\% \mathrm{~d}^{-1}$. Hence, the Petit-Saut reservoir can be considered as a reactor that deeply altered $\mathrm{Hg}$ speciation in favor of the methylated species. With balanced contributions, the main sites for water

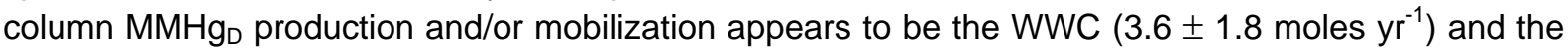
SWI $\left(3.7 \pm 1.2\right.$ moles $\left.\mathrm{yr}^{-1}\right)$. This bimodal distribution of $\mathrm{MMHg}_{\mathrm{D}}$ sources reflects many geochemical processes: (i) a potential mobilization of $\mathrm{MMHg}$ associated with the particles from the water column occurring during their degradation, (ii) a net methylation mechanism and/or (iii) a permanent efflux of $\mathrm{MMHg}_{\mathrm{D}}$ at the SWI. However, the observed relationship between $\mathrm{MMHg}_{\mathrm{D}}$ and sulfides lends support to the hypothesis of neutral $\mathrm{Hg}$-S complexes controlling the bioavailability of inorganic $\mathrm{Hg}$ for SRB methylation (Benoit et al., 2001 and 2003).

\section{Aknowledgments}

Thanks are due to J. Knoery for his helpful comments on an early version of the manuscript and to Heidi Pethybridge for editing the transcript. We also thank B. Burban, C. Reynouard, P. Cerdan, V. Horeau, R. Aboïkoni, L. Guillemet, and R. Vigouroux for their participation and facilitation to sampling and analyses. This work has been financially supported by CNRS (Conseil National de la Recherche Scientifique) and EDF (Electricité de France) grant $N^{\circ}$ F01381/0.

\section{References}

Ameel, J., Ruzycki, E., Axler, R. P., 1998. Analytical chemistry and quality assurance procedures for natural water samples. 6th edition. Central Analytical Laboratory, NRRI Tech. Rep. NRRI/TR98/03.

Amyot, M., Mierle, G., Lean, D., McQueen, D. J., 1997b. Effect of solar radiation on the formation of dissolved gaseous mercury in temperate lakes. Geochimica et Cosmochimica Acta 61, 975-987.

Barriel, L. A., Yi, Y., Leaitch, W. R., Lohmann, U., Kasibhatla, P., Roelofs, G. J., Wilson, J., McGovern, F., Benkovitz, C., Mélières, M. A., Law, K., Prospero, J., Kritz, M., Bergmann, D., Bridgeman, C., Chin, M., Christensen, J., Easter, R., Feichter, J., Land, C., Jeuken, A., Kjellström, E., Koch, D.,, Rasch P., 2001. A comparison of large scale atmospheric sulphate aerosols models (COSAM) overview and highlights. Tellus 53B. 
Benoit, J. M., Gilmour, C. C., Heyes, A., Mason, R. P., Miller, C. L., 2003. Geochemical and biological controls over mercury production and degradation in aquatic systems. Biogeochemistry of Environmentally Important Trace Elements 835, 262-297.

Benoit, J. M., Mason, R. P., Gilmour, C. C., Aiken, G. R., 2001. Constants for mercury binding by dissolved organic matter isolates from the Florida Everglades. Geochimica et Cosmochimica Acta 65, 4445-445.

Benoit, J. M., Gilmour, C. C. Mason, R. P., Heyes, A, 1999. Sulfide Controls on Mercury Speciation and Bioavailability to Methylating Bacteria in Sediment Pore Waters. Environmental Science \& Technology 33, 951-957.

Beucher, C., Wong, W. C. P., Richard, C., Mailhot, G., Bolte, M., Cossa, D., 2002. Dissolved gaseous mercury formation under UV irradiation of unamended tropical waters from French Guiana. Science of the Total Environment 290, 131-138.

Bloom, N. S., 1989. Determination of picogram levels of methylmercury by aqueous phase ethylation followed by cryogenic gas chromatography with cold vapour atomic fluorescence detection. Canadian Journal of Fisheries and Aquatic Sciences 46, 1131-1140.

Bloom, N. S., Fitzgerald, W. F., 1988. Determination of volatile mercury species at picogram level by low temperature gas chromatography with cold-vapour atomic fluorescence detection. Analytica Chimica Acta 28, 151-161.

Bothner, M. H., Jahnke, R. A., Peterson, M. L., Carpenter, R., 1980. Rate of mercury loss from contaminated estuarine sediments. Geochimica et Cosmochimica Acta 44, 273-285.

Boudou, A., Maury-Brachet, R., Coquery, M., Durrieux, G., Cossa, D., 2005. Synergic effect of goldmining and damming on mercury contamination in fish. Environmental Science \& Technology 39 , 2448-2454.

Canavan, M., Caldwell, C. A., Bloom, N. S., 2000. Discharge of methylmercury-enriched hypolimnetic water from a stratified reservoir. The Science of the Total Environment 260, 159-170.

Coelho-Souza, S. A., Guimaraes, J. R. D., Mauro, J. B. N., Miranda, M. R., Azevedo, S. M. F. O., 2006. Mercury methylation and bacterial activity associated to tropical phytoplankton. Science of the Total Environment, 364: 188-199.

Compeau, G., Bartha, R., 1985. Sulfate reducing bacteria: principal methylators of $\mathrm{Hg}$ in anoxic estuarine sediments. Applied Environmental Microbiology 50, 498-502.

Coquery, M., Cossa, D., Azemard, S., Peretyazhko, T., and Charlet, L., 2003: Methylmercury formation in the anoxic waters of the Petit-Saut reservoir (French Guiana) and its spreading in the adjacent Sinnamary River. Journal de Physique IV, 107, 327-331.

Cossa, D., Coquery, M., Nakhlé, K., and Claisse, D., 2002. Dosage du mercure total et du monomethylmercure dans les organismes et les sédiments marins. Méthodes d'analyse en milieu marin, Editions Ifremer, 27pp; ISBN 2-84433-105-X.

Cossa, D., Averty, B., Bretaudeau, J., and Sénard, A.S., 2003. Spéciation du mercure dissous dans les eaux marines. Méthodes d'analyse en milieu marin, Editions Ifremer, 27 pp; ISBN 2-84433-125-4.

Cossa, D., Mason, R. P.,, Fitzgerald, W. F., 1994. Chemical Speciation of Mercury in a Meromictic Lake. Chap. I.5. pp. 57-67; In: Mercury Pollution Integration and Synthesis, Watras C.J. et Huckabee, J.W. Lewis Publishers.

De Junet, A., 2004. Etude qualitative de la matière organique particulaire dans le réservoir de PetitSaut (Guyane Française): Composition Isotopique $\left(\delta^{13} \mathrm{C}\right)$, élémentaire $(\mathrm{C} / \mathrm{N})$ et pigmentaire. Rapport Master Talence, $41 \mathrm{pp}$.

Devereux, R., Winfrey, M. R., Winfrey, J., Stah, D. A., 1996. Depth profile of sulfate-reducing bacterial ribosomal RNA and mercury methylation in an estuarine sediment FEMS. Microbiology Ecology 20, 23-31.

Dumestre, J. F., Emilio, C. O., Ramon, M., Pedros-Alio, C., 2001. Changes in bacterial assemblages in a equatorial river induced by water eutrophication of Petit-Saut dam reservoir (French Guiana). Aquat. Microb. Ecol. 26, 209-221.

Dumestre, J.-F., Vaquer, A., Gosse, P., Richard, S., and Labroue, L., 1999. Bacterial ecology of a young equatorial hydroelectric reservoir (Petit-Saut, French Guiana). Hydrobiologia 400, 75-83.

Dumestre, J.-F., Labroue, L., Galy-Lacaux, C., Reynouard, C., Richard, S., 1997. Biomasses et activités bactériennes dans la retenue et à l'aval du barrage de Petit-Saut (Guyane): influence sur les émissions du méthane et la consommation d'oxygène. Hydroécologie Appliquée 9, 139-167.

Durrieu, G., Maury-Brachet, R., Boudou, A., 2005. Gold-mining and mercury contamination of the piscivorous fish Hoplias aimara in French Guiana (Amazon basin). Ecotoxicology and Environmental Safety $60,315-323$.

Gilmour, C. C., Henry, E. A., and Mitchell, R., 1992. Sulfate Stimulation of Mercury Methylation in Freshwater Sediments. Environmental Science \& Technology 26, 2281-2287. 
Gilmour, C. C., Henry E. A., 1991. Mercury methylation in aquatic systems affected by acid deposition. Environmental Pollution 71, 131-169.

Guedron, S., Grimaldi, C., Chauvel, C., Spadini, L., Grimaldi, M., 2006. Weathering versus atmospheric contributions to mercury concentrations in French Guiana soils. Applied Geochemistry. 21, 2010-2022.

Guimaraes, J. R. D., Roulet, M., Lucotte M., Mergler, D., 2000a. Mercury methylation along a lakeforest transect in the Tapajós river floodplain, Brazilian Amazon: seasonal and vertical variations. The Science of the Total Environment 261, 91-98.

Guimaraes, J. R. D., Meili, M., Hylander L. D., Silva, E., Roulet M., Mauro J. B. N., Lemos, R. A., 2000b. Mercury net methylation in five tropical flood plain regions of Brazil: high in the root zone of floating macrophyte mats but low in surface sediments and flooded soils. The Science of the Total Environment 261, 99-107.

Gunnison, D., Engler, R. M., and Patrick, W. H., Jr., 1985. Microbial processes in reservoirs. Dr W. Junk Publishers Dordrecht, 39pp.

Horeau, V., Richard, S., Cerdan, P., Aboiboni, R., Guillemet, L., Reynouard, C., Valere, J., Zouiten, C., 1999. Variabilités temporelles de la qualité physico-chimique et biologique des eaux liées au barrage hydroélectrique de Petit-Saut (Guyane française). 4th International Congress on Limnology and Oceanography, Bordeaux.

Hurley, J. P., Benoit, J. M., Babiarz, C. L., Shafer, M. M., Andren, A. W., Sullivan, J. R., Hammond, R., Webb, D. A., 1995. Influences of watershed characteristics on mercury levels in Wisconsin rivers. Environmental Science \& Technology 29, 1867-1875.

Jensen, S., Jernelöv, A., 1969. Biological Methylation of Mercury in Aquatic Organisms. Nature 223, 753-754.

King, J. K., Kostka, J. E., Frischer, M. E., Saunders, F. M., and Jahnke R. A., 2001. A quantitative relationship that demonstrates mercury methylation rates in marine sediments are based on the community composition and activity of sulfate-reducing bacteria. Environmental Science \& Technology 35, 2491-2496.

King, J. K., Saunders, F. M., Lee, R. F., Jahnke, R. A., 1999. Coupling mercury methylation rates to sulfate reduction rates in marine sediments. Environmental Toxicology and Chemistry 18, 1362-1369.

Korthals, E. T., Winfrey, M. R. 1987. Seasonal and Spatial Variations in Mercury Methylation and Demethylation in an Oligotrophic Lake. Environmental Microbiology, 53: 2397-2404.

Lacerda, L. D., Ribeirto, M. G., Cordeiro, R. C., Sofeddine, A., Turcq, B., 1999. Atmospheric mercury deposition over Brazil during the past 30,000 years. Ciência e Cultura 51, 363-371.

Lamborg, C. H., Rolfhus, K. R., Fitzgerald, W. F., Kim, G., 1999. The atmospheric cycling and air-sea exchange of mercury species in the South and equatorial Atlantic Ocean. Deep Sea Research 46, 957-977.

Lee, Y.-H., Iverfeldt. A., 1991. Measurement of methylmercury and mercury in runoff, lake and rain waters. Water Air Soil Pollution 56, 309-321.

Leermarkers, M., Galetti, S., De Galan, S., Brion, N., and Baeyens, W., 2001. Mercury in the Souther North Sea and Sheldt Estuary. Marine Chemistry 75, 229-248.

Liang, L., Horvat, M.,, Bloom, N. S., 1994. An improved speciation method for mercury by GC/CVAFS after aqueous phase ethylation and room temperature precollection. Talanta 41, 371-379.

Mason, R. P., Lawrence, A. L., 1999. Concentration, distribution, and bioavailability of mercury and methylmercury in sediments of Baltimore harbor and Chesapeake Bay, Maryland, USA. Environmental Toxicology and Chemistry 18, 2438-2447.

Mason, R. P., Lawson, N. M, Lawrence, A. L., Joy, J. L., Lee, J. G., Sheu, G. R., 1999. Mercury in the Chesapeake Bay. Marine Chemistry 65, 77-96.

Mason, R. P., Lawson, N. M., Sullivan, K. A., 1997. The concentration, speciation and sources of mercury in Chesapeake Bay precipitation. Atmospheric Environment 31, 3541-3550.

Merck, 2001. Spectroquant Analysis System: safety in water analysis. www.mercksante.fr/ servlet/PB/show/1198020/w285103.pdf\#search=\%22spectroquant\%20iron\%20251\%22

Morrison, K. A., Watras, C. J., 1999. Mercury and methyl mercury in freshwater seston: direct determination at picogram per litre levels by dual filtration. Can. J. Fish. Aquat. Sci. 56, 760-766.

Muresan, B., Cossa, D., Richard, S., Burban, B., 2007. Mercury speciation and exchanges at the airwater interface of a tropical artificial reservoir, French Guiana. The Science of the Total Environment 385, 132-145.

Peltier, W. R., Caulfield, C. P., 2003. Mixing efficiency in stratified shear flows. Annual Review of Fluid Mechanics 35, 135-167. 
Peretyazhko, T., Van Capellen, P., Meile, C., Coquery, M., Musso, M., Regnier, P., Charlet, L., 2005. Biogeochemistry of major redox elements and mercury in a tropical reservoir lake (Petit-Saut, French Guiana). Aquatic Geochemistry 11, 33-35.

Peretyazhko, T., 2002. Formation de $\mathrm{Hg}^{0}$ dans les milieux aquatiques tropicaux (Lacs et sols). Ph.D thesis, Univ Grenoble, 161 pp.

Petot, J., 1993. Histoire de l'or en Guyane. L'Harmattan, Paris, 256 pp.

Richard, S., Arnoux, A., Cerdan, P., Reynouard, C., Horeau, V., Vigouroux, R., 2002. Influence of the setting up of a man-made lake on mercury levels in the flesh of fish in a neotropical habitat: the Sinnamary River (French Guiana). Rev. Ecol. 57, 2002.

Richard, S., 1996. La mise en eau du barrage de Petit-Saut. Hydrochimie 1 - du fleuve Sinnamary avant la mise en eau, 2 - de le retenue pendant la mise en eau, 3 - du fleuve en aval. Thèse de doctorat, Université d'Aix - Marseille I, 278 pp.

Roulet, M., Grimaldi, C., 2001. Le mercure dans les sols d'Amazonie. Origine et comportement du mercure dans les couvertures ferrallitiques du bassin amazonien et des Guyanes. Editions de I'IRD, collection Expertise collégiale, 121-166.

Roulet, M., Guimaraes J. R. D., Lucotte M., 2001. Methylmercury production and accumulation in sediments and soils of an Amazonian floodplain. Effect of seasonal inundation. Water, Air and Soil Pollution 128, 41-60.

Roulet, M., Lucotte, M., Guimaraes, J. R. D, 2000. Methylmercury in the water, seston and epiphyton of an Amazonian river and its floodplain, Tapajos river, Brazil. Sci. Total. Environ. 261, 43-59.

Roulet, M., Lucotte, M., Farella, N., Serique, G., Coelho, H., Soussa Passos, C.J., De Jessus da Silva, E., Scavone De Andrade, P., Mergler, D., Guimaraes, J.R.D., A. A., 1999. Effects of recent human colonization on the presence of mercury in amazonian ecosystem. Water, Air and Soil Pollution 112 , 297-313.

Roulet, M., Lucotte, M., Canuel, R., Rheault, I., Tran, S., De Freitos Gog, Y. G., Farella, N., Souza do Vale, R., Sousa Passos, C. J., De Jesus da Silva, E., Mergler, D., Amorim, M. 1998a - Distribution and partition of total mercury in waters of the Tapajós River Basin, Brazilian Amazon. Science of the Total Environment 213, 203-211.

Roulet, M., Lucotte, M., Canuel, R., Farella, N., Courcelles, M., Guimaraes, J. R. D., Mergler, D., Amorim, M., 1998b. The geochemistry of mercury in central Amazonian soils developed on the Alterdo-Chao formation of the lower Tapajos River Valley, Para state, Brazil. Science of the Total Environnement 223, 1-24.

Roulet; M., Lucotte, M., 1995. Geochemistry of mercury in pristine and flooded ferralitic soils of a tropical rain forest in French Guiana, South America. Water, Air and Soil Pollution 80, 1079-1088.

Schetagne, R., Verdon, R., 1999. Post-impoundment evolution of fish mercury levels at the La Grande complex, Québec, Canada (from 1978 to 1996). Environmental Science Series, Springer, 235-258.

Schuster, E., 1991. The behavior of mercury in the soil with special emphasis on complexation and adsorption processes-A review of literature. Water Air Soil Pollution 56, 667-680.

Surma-Aho, K., Rekolainen, J. P. S., Verta, M., 1986. Organic and inorganic mercury in the food chain of some lakes and reservoirs in Finland. Chemosphere 15, 353-372.

Tremblay, A., 1996. Methymercury in a benthic food web of two hydroelectric reservoirs and a natural lake of Northern Québec (Canada). Water, Air and Soil Pollution 91, 3-4.

Verdon, R., Brouard, D., Demers, C., Lalumière, R., Laperle, M., Schetagne, R., 1991. Mercury evolution (1978-1988) in fishes of the La Grande Hydroelectric Complex, Québec, Canada. Water, Air and Soil Pollution 56, 405-417.

Vizier, J.F., 1978. Étude de la dynamique du fer des sols évoluant sous l'effet d'un excès d'eau. Cah. ORSTOM, Pedol XVI, 23-41.

Xiao, Z.F., Stromberg, D., Lindqvist, O., 1995. Influence of humic substances on photolysis of divalent mercury in aqueous solution. Water, Air and Soil Pollution 80, 789-798.

Zahir, F., Rizwi, S. J., Haq K. S., Khan R. H., 2005. Low dose mercury toxicity and human health. Environmental Toxicology and Pharmacology 20, 351-360. 


\begin{tabular}{|c|c|c|c|c|c|c|c|c|c|}
\hline $\begin{array}{l}\text { Nature / } \\
\text { samples }\end{array}$ & rigin of the & $\begin{array}{c}\mathrm{HgT}_{\text {UNF }} \\
\left(\mathrm{pmol} \mathrm{L}^{-1}\right)\end{array}$ & $\begin{array}{c}\operatorname{HgT}_{\mathrm{D}} \\
\left(\mathrm{pmol} \mathrm{L}^{-1}\right)\end{array}$ & $\begin{array}{c}\operatorname{HgT}_{\mathrm{P}} \\
\left(\mathrm{pmol} \mathrm{g}{ }^{-1}\right)\end{array}$ & $\begin{array}{l}\left.\text { MMHgunF }_{\text {MMol L }}^{-1}\right) \\
\left(p^{2}\right.\end{array}$ & $\begin{array}{c}\mathrm{MMHg}_{\mathrm{D}} \\
\left(\mathrm{pmol} \mathrm{L}^{-1}\right)\end{array}$ & $\begin{array}{c}\mathrm{MMHg}_{\mathrm{P}} \\
\left(\mathrm{pmol} \mathrm{g}^{-1}\right)\end{array}$ & $\begin{array}{c}\text { DGM } \\
\left(p^{-1} L^{-1}\right)\end{array}$ & $\begin{array}{l}\mathrm{HgR}_{\mathrm{UNF}} \\
\left(\mathrm{pmol} \mathrm{L}{ }^{-1}\right)\end{array}$ \\
\hline \multicolumn{2}{|l|}{ Rain } & $\begin{array}{c}16 \pm 12(n=62) \\
(2.3-57.7)\end{array}$ & - & - & $\begin{array}{l}0.8 \pm 1.4(n=34) \\
\quad(0.05-10.2)\end{array}$ & - & - & - & $\begin{array}{c}3 \pm 3(n=60) \\
(0.10-20.8)\end{array}$ \\
\hline \multicolumn{2}{|c|}{ Sinnamary river (SD) } & $\begin{array}{c}13 \pm 2(n=4) \\
(10.8-15.6)\end{array}$ & $\begin{array}{c}8 \pm 1(n=4) \\
(6.1-8.8)\end{array}$ & $\begin{array}{c}1100 \pm 400(n=4) \\
(860-1800)\end{array}$ & $\begin{array}{c}0.7 \pm 0.2(n=4) \\
(0.54-0.75)\end{array}$ & $\begin{array}{c}0.5 \pm 0.2(n=4) \\
(0.35-0.53)\end{array}$ & $\begin{array}{c}25 \pm 15(n=4) \\
(17-44)\end{array}$ & $\begin{array}{c}0.38 \pm 0.15(\mathrm{n}= \\
4) \quad(0.24- \\
0.57)\end{array}$ & $\begin{array}{c}1.3 \pm 0.2(n=4) \\
(1.07-1.52)\end{array}$ \\
\hline \multirow{2}{*}{$\begin{array}{l}\text { Flooded } \\
\text { forest (FF) }\end{array}$} & Epilimnion & $\begin{array}{c}5 \pm 4(n=10) \\
(2.0-15.3)\end{array}$ & $\begin{array}{c}3 \pm 2(n=10) \\
(1.2-6.8)\end{array}$ & $\begin{array}{c}200 \pm 150(n=8) \\
(100-470)\end{array}$ & $\begin{array}{l}0.5 \pm 0.2^{*}(n=9) \\
\quad(0.17-0.79)\end{array}$ & $\begin{array}{c}0.3 \pm 0.2(n= \\
10)(0.10- \\
0.64)\end{array}$ & $\begin{array}{c}50 \pm 30(n=9) \\
(13-130)\end{array}$ & $\begin{array}{cc}0.17 & \pm 0.12(\mathrm{n}= \\
9) & (0.08- \\
& 0.44)\end{array}$ & $\begin{array}{c}0.7 \pm 0.3(n=3) \\
\quad(0.35-1.07)\end{array}$ \\
\hline & Hypolimnion & $\begin{array}{c}8 \pm 5(n=11) \\
(4.0-19.0)\end{array}$ & $\begin{array}{c}5 \pm 4(n=11) \\
(1.0-12.4)\end{array}$ & $\begin{array}{l}1300 \pm 750(n= \\
11) \quad(65-2300)\end{array}$ & $\begin{array}{l}1.8 \pm 1.1 *(n= \\
11) \quad(0.35- \\
3.63)\end{array}$ & $\begin{array}{c}0.5 \pm 0.1(\mathrm{n}= \\
11)(0.06- \\
0.94)\end{array}$ & $\begin{array}{c}230 \pm 200(\mathrm{n}= \\
11) \quad(58- \\
840)\end{array}$ & $\begin{array}{c}0.15 \pm 0.15(\mathrm{n}= \\
11) \\
-0.66)\end{array}$ & $\begin{array}{c}0.4 \pm 0.3(n=5) \\
(0.15-0.84)\end{array}$ \\
\hline \multirow{2}{*}{$\begin{array}{l}\text { Center } \\
\text { reservoir } \\
(\mathrm{CR})\end{array}$} & Epilimnion & $\begin{array}{c}5 \pm 1(n=12) \\
(3.8-7.7)\end{array}$ & $\begin{array}{c}4 \pm 1(n=12) \\
(1.4-5.6)\end{array}$ & $\begin{array}{c}230 \pm 200(n=12) \\
(40-810)\end{array}$ & $\begin{array}{l}1.3 \pm 1.0 *(n= \\
12) \quad(0.34- \\
3.84)\end{array}$ & $\begin{array}{l}0.3 \pm 0.3(\mathrm{n}= \\
12)(0.03- \\
1.07)\end{array}$ & $\begin{array}{c}100 \pm 100(n= \\
12) \underset{350)}{(7-}\end{array}$ & $\begin{array}{c}0.45 \pm 0.18(n= \\
12) \\
-0.76)\end{array}$ & $\begin{array}{c}0.5 \pm 0.4(n=4) \\
(<0.01-1.08)\end{array}$ \\
\hline & Hypolimnion & $\begin{array}{c}14 \pm 5(n=22) \\
(8.0-25.0)\end{array}$ & $\begin{array}{c}7 \pm 3(n=22) \\
(3.9-16.3)\end{array}$ & $\begin{array}{c}1500 \pm 1100(\mathrm{n}= \\
22) \quad(40- \\
5290)\end{array}$ & $\begin{array}{c}2.7 \pm 1.7 *(n= \\
22) \quad(0.49- \\
8.36)\end{array}$ & $\begin{array}{c}1.4 \pm 0.4(\mathrm{n}= \\
22)(0.13- \\
5.88)\end{array}$ & $\begin{array}{l}140 \pm 90(\mathrm{n}= \\
22) \\
410)\end{array}$ & $\begin{array}{c}0.28 \pm 0.13(n= \\
22) \\
-0.51)\end{array}$ & $\begin{array}{c}0.3 \pm 0.3(n=6) \\
(<0.01-0.89)\end{array}$ \\
\hline \multirow{2}{*}{$\begin{array}{l}\text { Upstream } \\
\text { dam (UD) }\end{array}$} & Epilimnion & $\begin{array}{c}5 \pm 2(n=13) \\
(2.7-8.9)\end{array}$ & $\begin{array}{c}4 \pm 2(n=13) \\
(1.0-8.8)\end{array}$ & $\begin{array}{c}130 \pm 100(n=11) \\
(15-440)\end{array}$ & $\begin{array}{c}1.0 \pm 0.4^{*}(\mathrm{n}= \\
13) \quad(0.28- \\
1.85)\end{array}$ & $\begin{array}{c}0.3 \pm 0.2(\mathrm{n}= \\
13)(0.04- \\
1.13)\end{array}$ & $\begin{array}{l}100 \pm 75(\mathrm{n}= \\
13) \begin{array}{l}(27- \\
290)\end{array}\end{array}$ & $\begin{array}{l}0.32 \pm 0.12(n= \\
13) \\
-0.57)\end{array}$ & $\begin{array}{c}0.6 \pm 0.3(n=9) \\
(0.28-0.96)\end{array}$ \\
\hline & Hypolimnion & $\begin{array}{c}14 \pm 6(n=10) \\
(7.7-21.9)\end{array}$ & $\begin{array}{c}9 \pm 6(n=10) \\
(3.0-19.4)\end{array}$ & $\begin{array}{c}1300 \pm 1100(n= \\
10)(86-4210)\end{array}$ & $\begin{array}{c}2.3 \pm 1.1^{*}(\mathrm{n}= \\
10) \quad(1.24- \\
5.03)\end{array}$ & $\begin{array}{c}0.8 \pm 0.5(\mathrm{n}= \\
10)(0.22- \\
2.54)\end{array}$ & $\begin{array}{l}140 \pm 60(\mathrm{n}= \\
10)_{340)}^{(66-}\end{array}$ & $\begin{array}{c}0.43 \pm 0.28(\mathrm{n}= \\
10) \\
-0.74)^{(0.07}\end{array}$ & $\begin{array}{c}0.4 \pm 0.2(n=9) \\
(0.12-0.69)\end{array}$ \\
\hline \multicolumn{2}{|c|}{ Epilimnion (FF+CR+UD) } & $\begin{array}{c}5 \pm 3(n=35) \\
(2.0-15.3)\end{array}$ & $\begin{array}{c}4 \pm 2(n=35) \\
(1.0-8.8)\end{array}$ & $\begin{array}{c}200 \pm 150(n=31) \\
(15-810)\end{array}$ & $\begin{array}{c}0.9 \pm 0.6^{*}(n= \\
34)(0.17-3.84)\end{array}$ & $\begin{array}{c}0.3 \pm 0.2(n= \\
35)(0.03-1.13)\end{array}$ & $\begin{array}{c}80 \pm 70(n=34) \\
(7-350)\end{array}$ & $\begin{array}{c}0.3 \pm 0.2(n=34) \\
\quad(0.08-0.76)\end{array}$ & $\begin{array}{c}0.5 \pm 0.3(\mathrm{n}= \\
16)(<00.1- \\
1.08)\end{array}$ \\
\hline
\end{tabular}




\begin{tabular}{|c|c|c|c|c|c|c|c|c|}
\hline Hypolimnion (FF+CR+UD) & $\begin{array}{c}13 \pm 6(n=43) \\
(4-25)\end{array}$ & $\begin{array}{c}8 \pm 4(n=43) \\
(1.0-19.4)\end{array}$ & $\begin{array}{c}1300 \pm 950(n=37) \\
(40-5290)\end{array}$ & $\begin{array}{l}2.2 \pm 1.0 *(n=43) \\
\quad(0.35-8.36)\end{array}$ & $\begin{array}{c}0.9 \pm 0.5(n= \\
43)(0.06-5.88)\end{array}$ & $\begin{array}{l}170 \pm 90(n= \\
43)(15-840)\end{array}$ & $\begin{array}{l}0.2 \pm 0.2(n=43) \\
\quad(0.07-0.74)\end{array}$ & $\begin{array}{c}0.4 \pm 0.3(n= \\
20)(<0.01- \\
0.89)\end{array}$ \\
\hline Tailrace (CS) & $\begin{array}{c}13 \pm 5(n=88) \\
(3.7-27.9)\end{array}$ & $\begin{array}{c}8 \pm 2(n=27) \\
(0.5-10.7)\end{array}$ & $\begin{array}{c}800 \pm 700(n=27) \\
(32-3310)\end{array}$ & $\begin{array}{c}2.5 \pm 1.5(n=27) \\
\quad(0.30-8.40)\end{array}$ & $\begin{array}{c}1.6 \pm 0.7(\mathrm{n}= \\
27)(0.11- \\
2.94)\end{array}$ & $\begin{array}{c}150 \pm 100(n= \\
27) \quad(27- \\
320)\end{array}$ & $\begin{array}{l}0.30 \pm 0.20(\mathrm{n}= \\
50) \quad(0.06- \\
0.95)\end{array}$ & $\begin{array}{c}2.3 \pm 0.5(n= \\
88)(<0.47- \\
16.35)\end{array}$ \\
\hline
\end{tabular}

Table 1. Summary statistics on mercury species concentrations: total mercury $\left(H_{g} T_{U N F}, H_{g} T_{D}, H_{g} T_{P}\right)$, monomethylmercury $\left(M M H g_{U N F}, M_{M H} g_{D}, M_{M H} g_{P}\right)$, dissolved gaseous mercury (DGM) and reactive mercury (HgR) in various compartments constitutive of the Petit-Saut reservoir; mean \pm standard deviation, $(n)$ number of determination, range in brackets. Subscript D and $P$ refer to dissolved and particulate phases respectively; subscript UNF corresponds to unfiltered samples, except data with an asterisk which are calculated from $\mathrm{MMHg}_{\mathrm{D}}, \mathrm{MMHg}_{\mathrm{P}}$ and SPM. 


\begin{tabular}{lccc}
\hline \hline Nature of the sample & Station & $\mathrm{HgT}_{\mathrm{P}}(\mathrm{pmol} \mathrm{g})$ & $\mathrm{MMHg}_{\mathrm{P}}(\mathrm{pmol} \mathrm{g})$ \\
$\begin{array}{l}\text { Sediment from trap }(7 \mathrm{~m}) \\
\text { Sediment from trap (20 }\end{array}$ & CR & $950 \pm 60(\mathrm{n}=3)$ & $26 \pm 7(\mathrm{n}=2)$ \\
$\begin{array}{l}\text { m) } \\
\text { Sediment from trap (30 } \\
\text { m) }\end{array}$ & CR & $1800 \pm 130(\mathrm{n}=3)$ & $30 \pm 12(\mathrm{n}=2)$ \\
\hline $\begin{array}{l}\text { Slurries } \\
\text { Slurries }\end{array}$ & FF & $400 \pm 250(\mathrm{n}=3)$ & $90 \pm 20(\mathrm{n}=3)$ \\
Slurries & CR & $1100 \pm 400(\mathrm{n}=3)$ & $120 \pm 50(\mathrm{n}=3)$ \\
\hline
\end{tabular}

Table 2. Mercury concentrations in particles from the sediment traps and accumulated slurries at the sediment-water interface from the Petit-Saut reservoir.

\begin{tabular}{lcc}
\hline Sampling sites & $\begin{array}{c}\text { Mean } \mathrm{HgT}_{\mathrm{D}} \text { concentrations } \\
\left(\mathrm{pmol} \mathrm{L}^{-1}\right)\end{array}$ & $\begin{array}{c}\text { Mean } \mathrm{MMHg}_{\mathrm{D}} \text { concentrations } \\
\left(\mathrm{pmol} \mathrm{L}^{-1}\right)\end{array}$ \\
\hline Sinnamary (Saut-Dalles) & $9 \pm 3(\mathrm{n}=6)$ & $0.3 \pm 0.1(\mathrm{n}=5)$ \\
Courcibo & $16 \pm 3(\mathrm{n}=2)$ & $0.34 \pm 0.07(\mathrm{n}=2)$ \\
Leblond & $14 \pm 4(\mathrm{n}=4)$ & $0.34 \pm 0.07(\mathrm{n}=4)$ \\
\hline
\end{tabular}

Table 3. Dissolved total $\left(\mathrm{HgT}_{\mathrm{D}}\right)$ and monomethyl $\left(\mathrm{MMHg}_{\mathrm{D}}\right)$ mercury from December 2004 and March 2005 sampling campaigns of main tributaries of the Petit-Saut reservoir. According to Coquery et al. (2003), during the 1999 wet and dry seasons, the $\mathrm{HgT}_{\mathrm{D}}$ mean concentrations orderly were (i) $15 \pm 2$ and $41 \pm 6 \mathrm{pmol} \mathrm{L}^{-1}$ in Leblond and (ii) $12 \pm 2$ and $8 \pm 1 \mathrm{pmol} \mathrm{L}^{-1}$ in Courcibo creeks. The respective $\mathrm{MMHg}_{\mathrm{D}}$ concentrations were (i) $0.20 \pm 0.04$ and $0.31 \pm 0.05 \mathrm{pmol} \mathrm{L}^{-1}$ in Leblond and (ii) $0.13 \pm 0.03$ and $0.16 \pm 0.04$ pmol L $^{-1}$ in Courcibo creeks. 


\begin{tabular}{lcc|cc}
\hline \hline $\begin{array}{l}\text { Compoun } \\
\text { ds }\end{array}$ & $\begin{array}{c}\text { Dry season }\left(\mathrm{mol} \mathrm{d}^{-}\right. \\
\mathrm{c}^{-} \\
(15 / 07 / 03- \\
15 / 12 / 03)\end{array}$ & $\begin{array}{c}\text { Wet season }\left(\mathrm{mol} \mathrm{d}^{-1}\right) \\
(01 / 04 / 03-15 / 07 / 03)\end{array}$ & $\begin{array}{c}\text { Annual }\left(\mathrm{mol} \mathrm{yr}^{-1}\right) \\
(18 / 03 / 03- \\
17 / 03 / 04)\end{array}$ & $\begin{array}{c}\text { Annual }\left(\mathrm{mol} \mathrm{yr}^{-1}\right) \\
(1 / 10 / 03-30 / 09 / 04)\end{array}$ \\
\hline DGM & $4.010^{-3}$ & $3.310^{-3}$ & 1.3 & 2.0 \\
HgR $_{\text {UNF }}$ & 0.03 & 0.02 & 9.5 & 16 \\
MMHguNF $_{\text {HMT }}$ & 0.03 & 0.06 & 6.5 & 13.5 \\
HgT $_{\text {UNF }}$ & 0.21 & 0.16 & 61.5 & 79 \\
\hline
\end{tabular}

Table 4. Mercury exportation from the reservoir for various periods. The calculated fluxes are the cumulative weekly fluxes (concentration multiplied water discharge) for the reference period. 


\section{Figures}

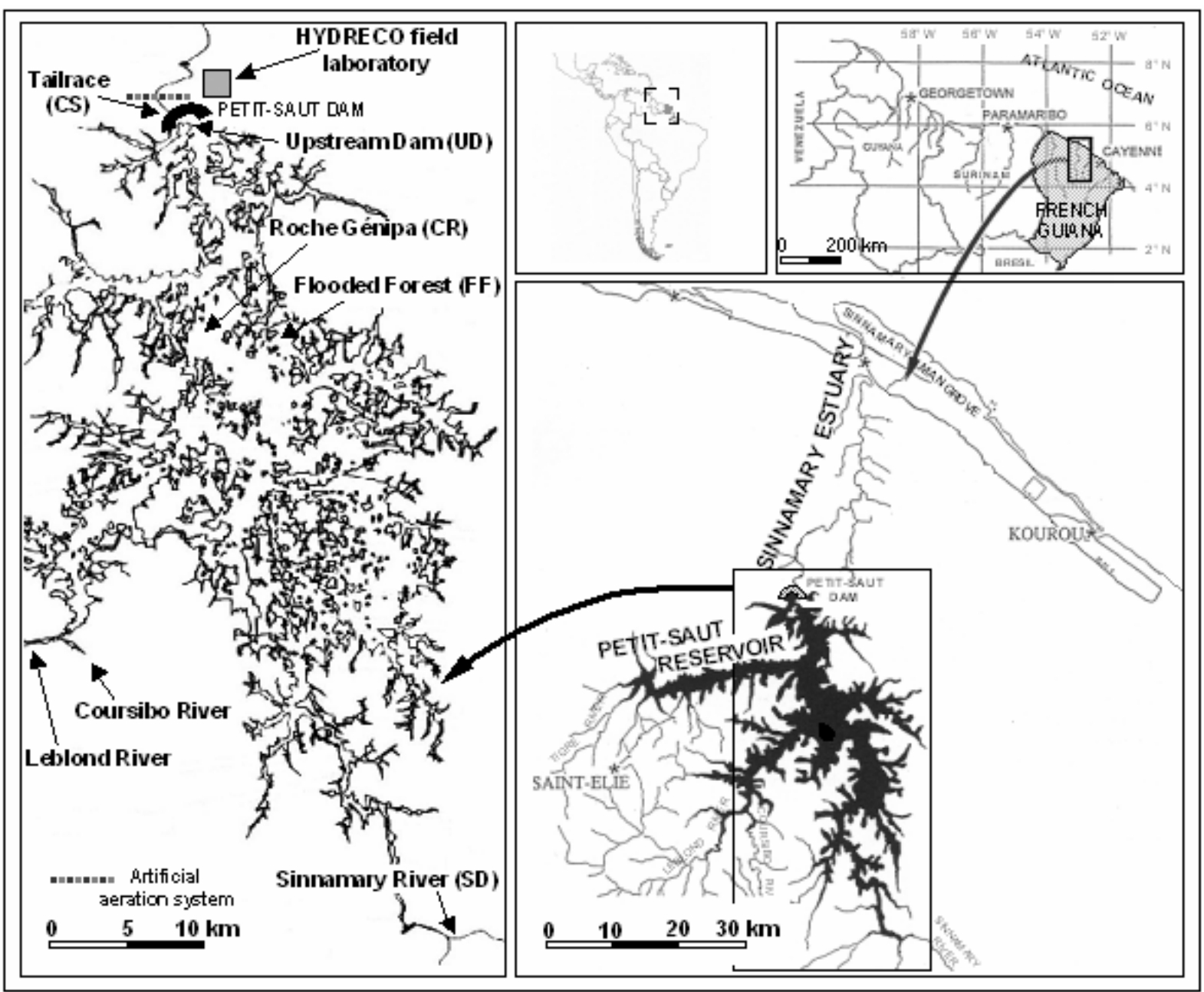

Fig. 1.

Figure 1. Study area. The flooded forest (FF), Roche Génipa (CR), upstream dam (UD) and tailrace (CS) stations were systematically investigated during Matoutou 1 (March-April 2003), 2 (JanuaryFebruary 2004) and 3 (May-June 2004) campaigns. The Sinnamary, Leblond and Coursibo streams were studied during Matoutou 4 (November-December/2004) and 5 (March-April/2005). 

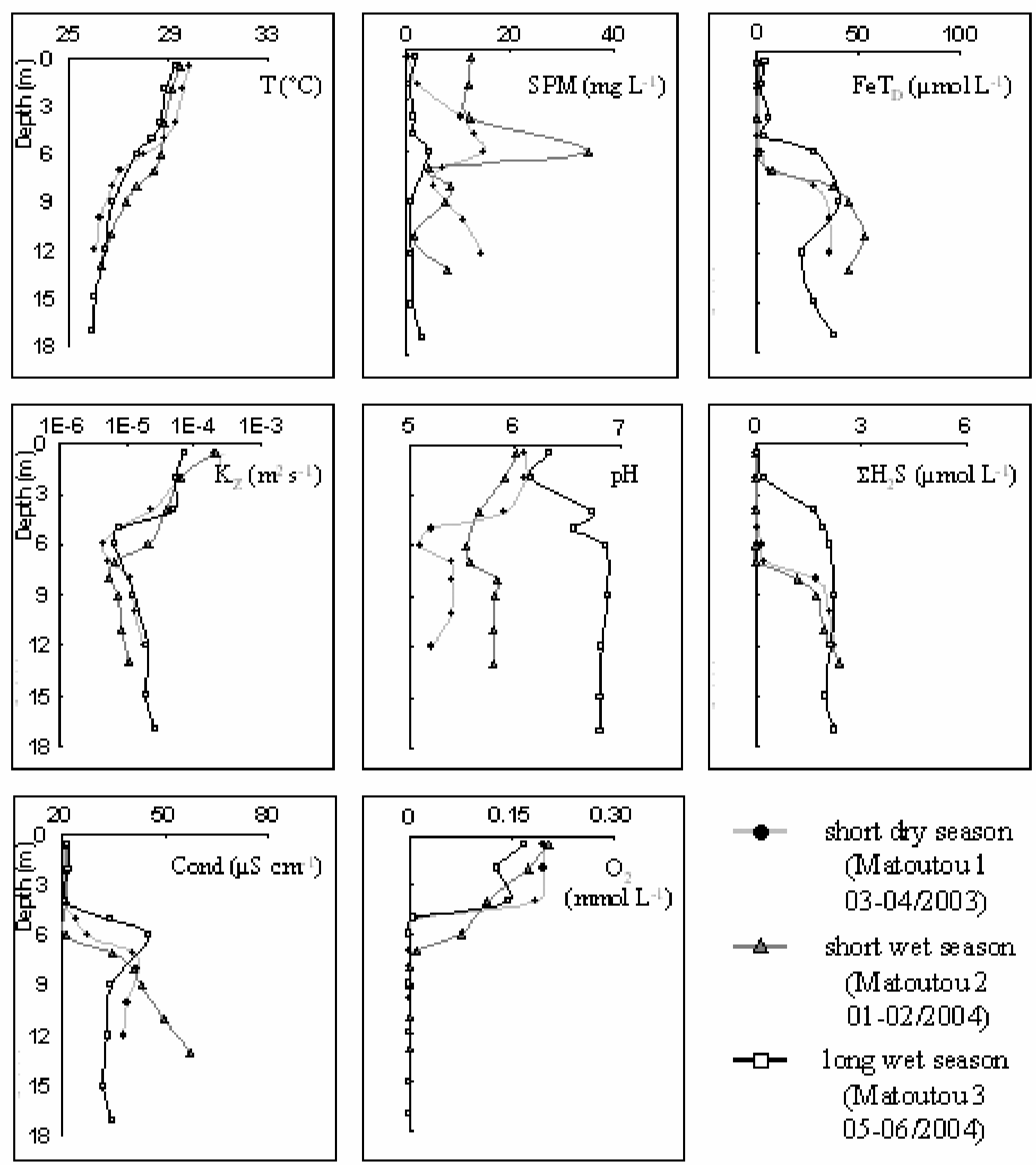

- short dry season

(Matoutou 1 03-04/2003)

$\triangle \quad$ short wet season (Matoutou2 $01-02 / 2004)$

$\rightarrow-$ long wet season

(Matoutou3 05-06/2004)

Fig. 2.A. 


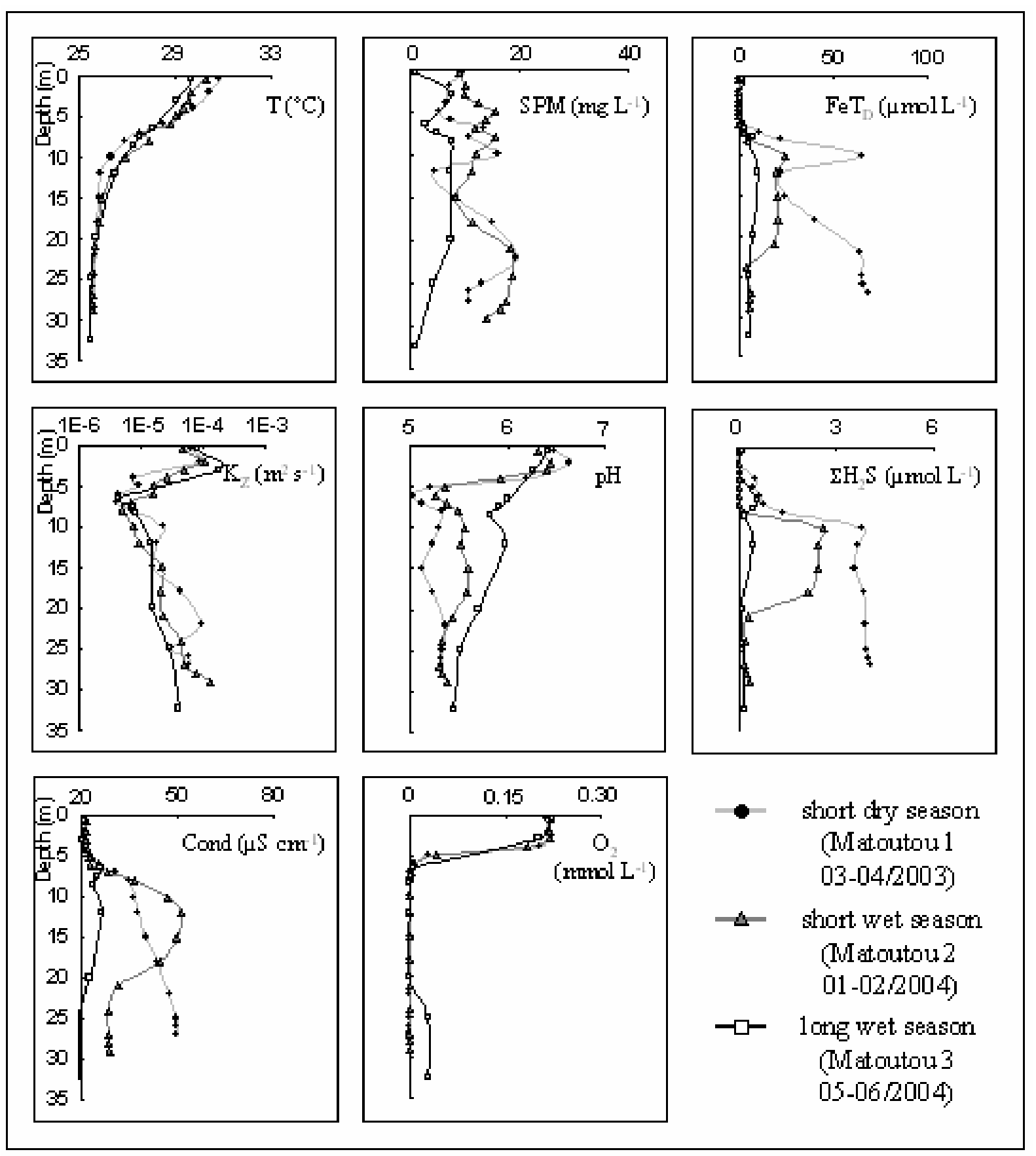

Fig. 2.B. 


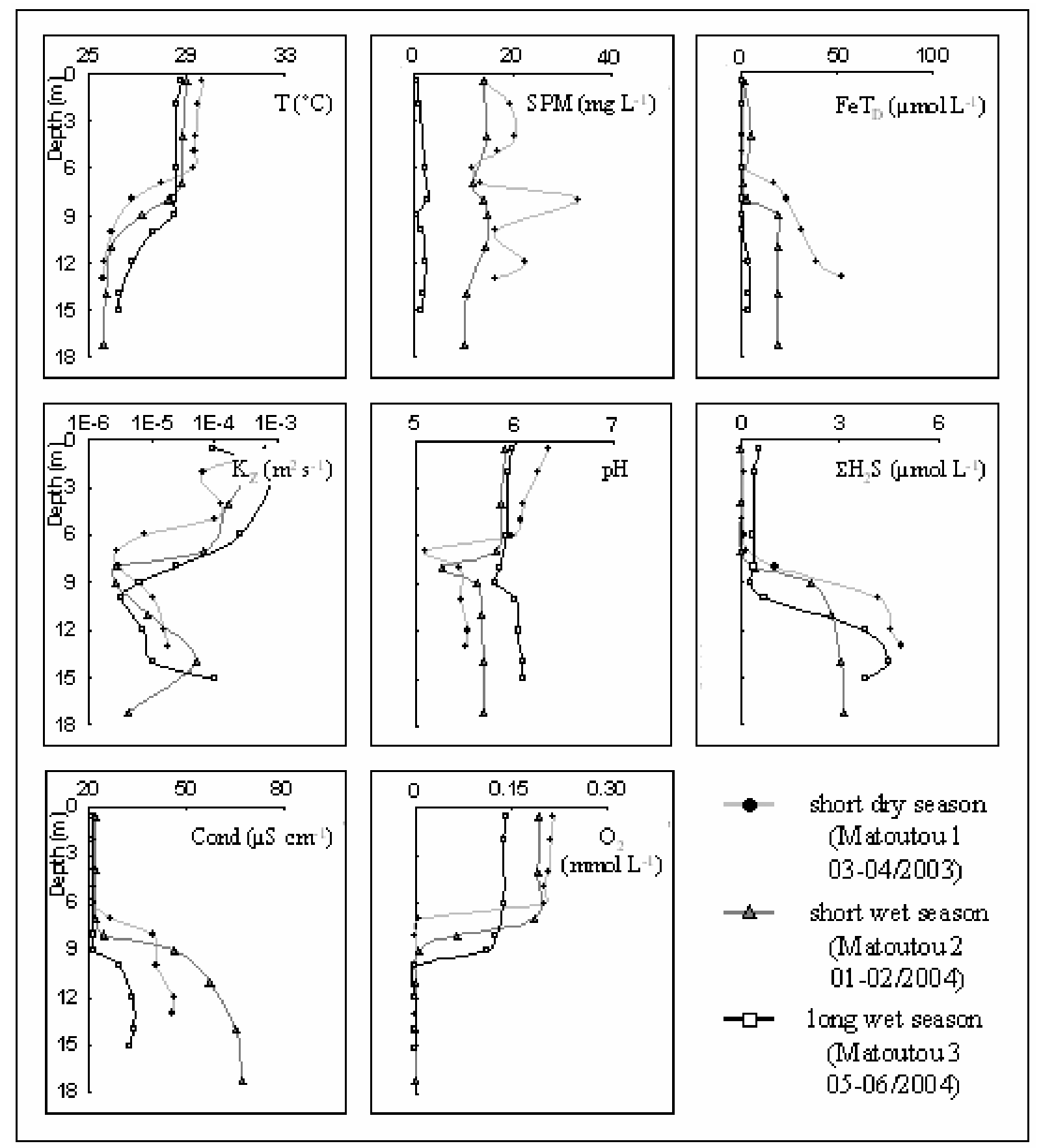

Fig. 2.C.

Figure 2. Water column profiles of main physical characteristics and major chemical compounds at $A$ : Flooded Forest (FF), B: Roche Génipa (CR) and C: upstream dam (UD) stations. Each graph displays the distribution of a same parameter with regard to Matoutou 1, 2 and 3 campaigns. 




Fig. 3.A. 


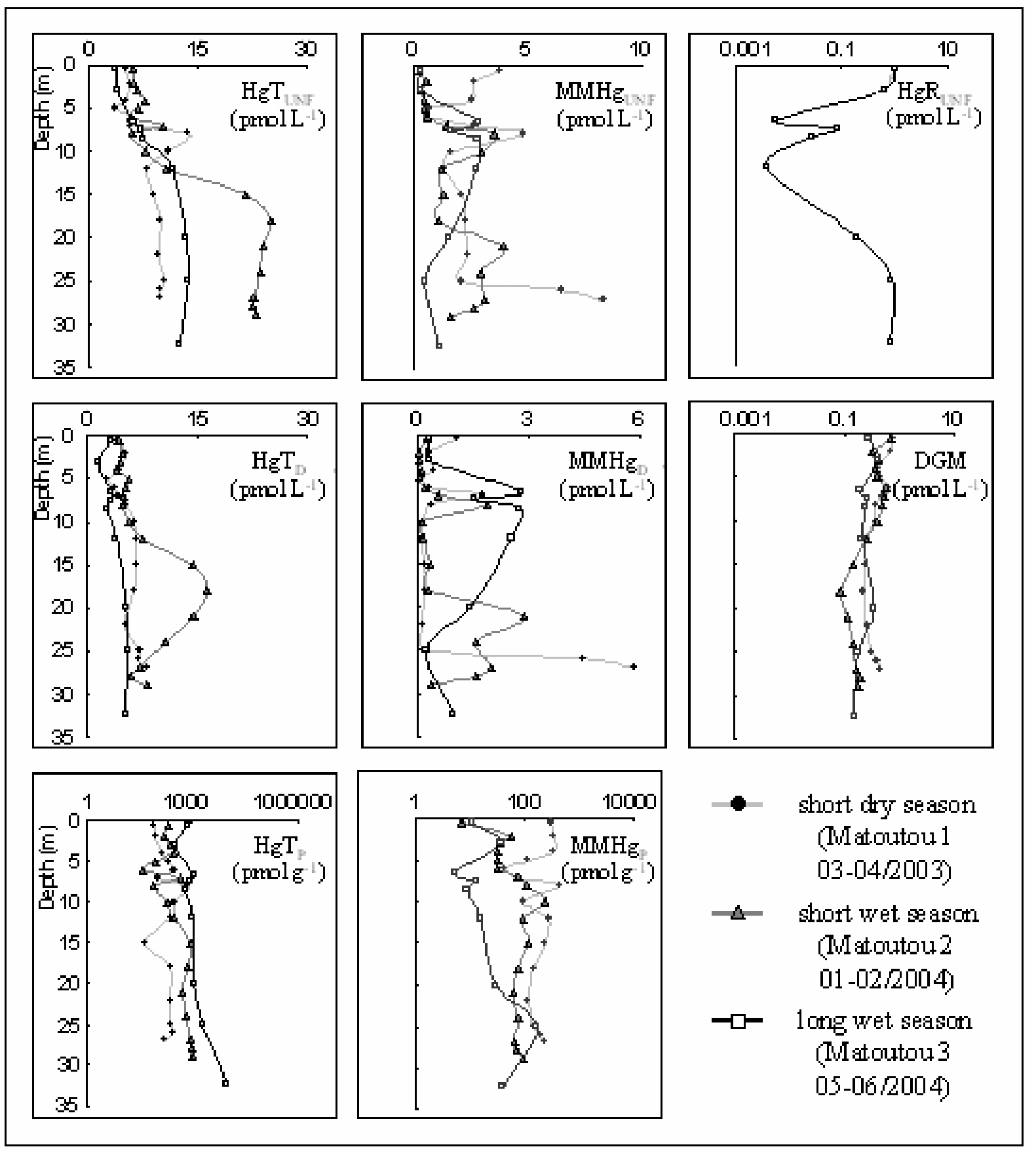

Fig. 3.B. 

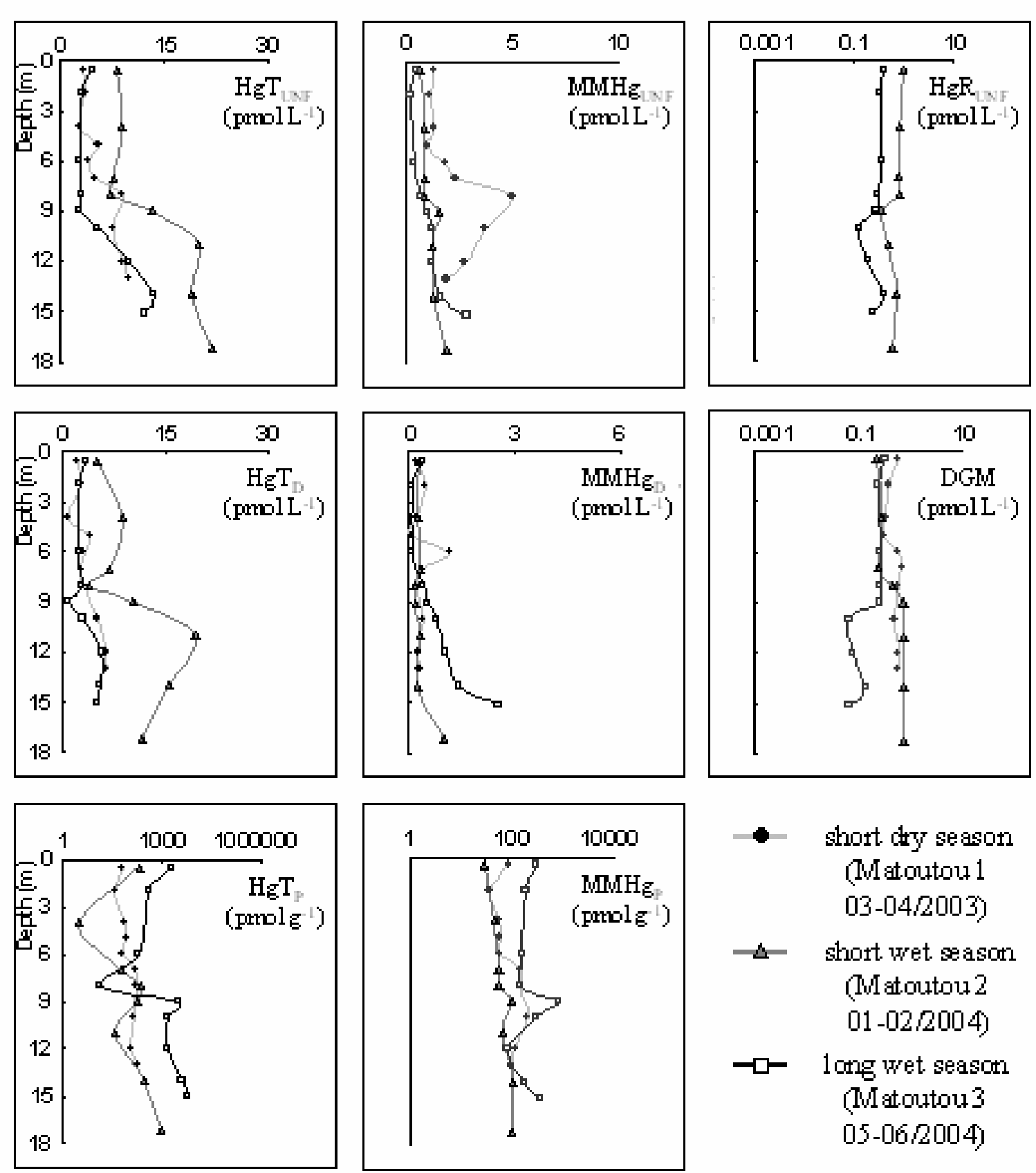

- short dry season

(Matoutou 1 03-04/2003)

$\rightarrow \quad$ short wet season

(Matoutou2

$01-02 / 2004)$

$\rightarrow-1$ long wet season

(Matoutou3

$05-06 / 2004)$

Fig. 3.C.

Figure 3. Water column profiles of main Hg species at A: Flooded Forest (FF), B: Roche Génipa (CR) and C: upstream dam (UD) stations. Each graph displays the distribution of same specie with regard to Matoutou 1, 2 and 3 campaigns. 


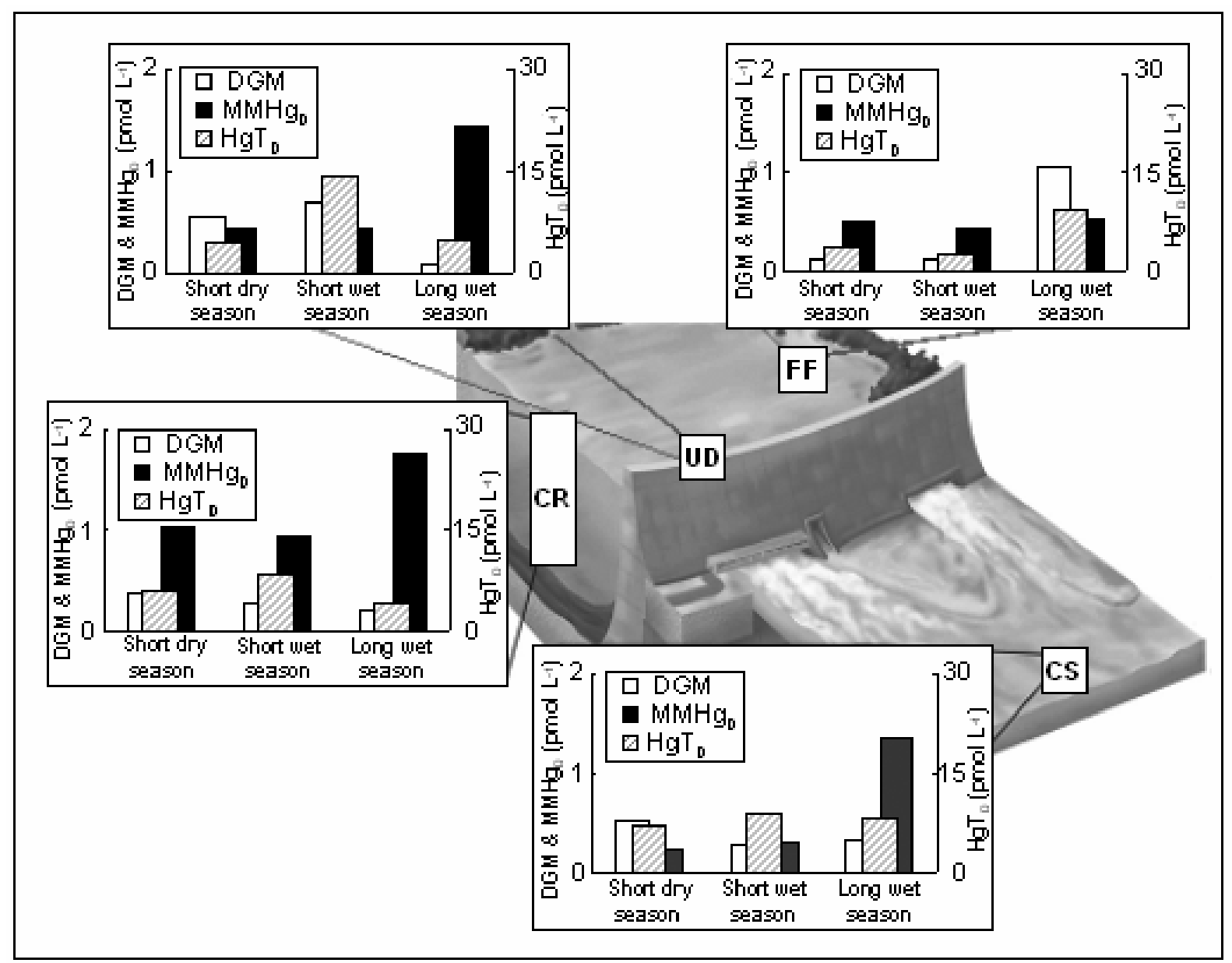

Fig. 4.

Figure 4. Average concentrations of main dissolved species of mercury $\left(\mathrm{HgT}_{\mathrm{D}}, \mathrm{MMHg}_{\mathrm{D}}\right.$ and $\left.\mathrm{DGM}\right)$ within the hypolimnion of reservoir and dam discharged waters. To illustrate the seasonal variability, average concentrations were reported for every sampled station with distinction between Matoutou 1 (short dry season), 2 (short wet season) and 3 (long wet season) campaigns. 


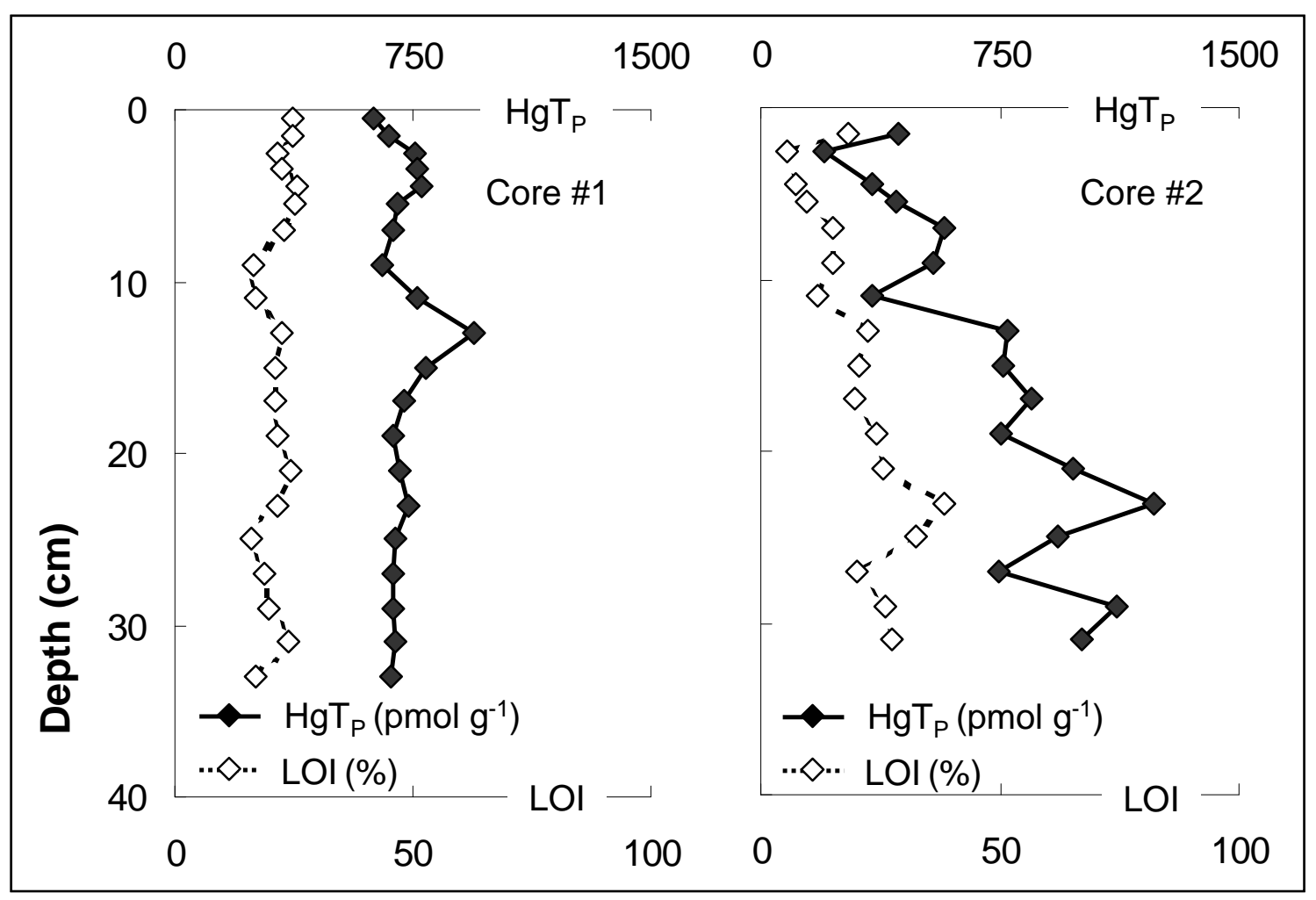

Fig. 5.

Figure 5. Profiles of total particulate mercury $\left(\mathrm{HgT}_{\mathrm{P}}\right.$; filled diamonds) and percentage of loss on ignition (LOI; open diamonds) in sediments. Both cores were collected in the riverbed of the Sinnamary River: core \#1 originated from the Saut Dalles (SD) station $(11 \mathrm{~km}$ ahead of the reservoir entrance) while core \#2 was collected further down the Takari-Tanté fall (200 m inside the reservoir itself). 


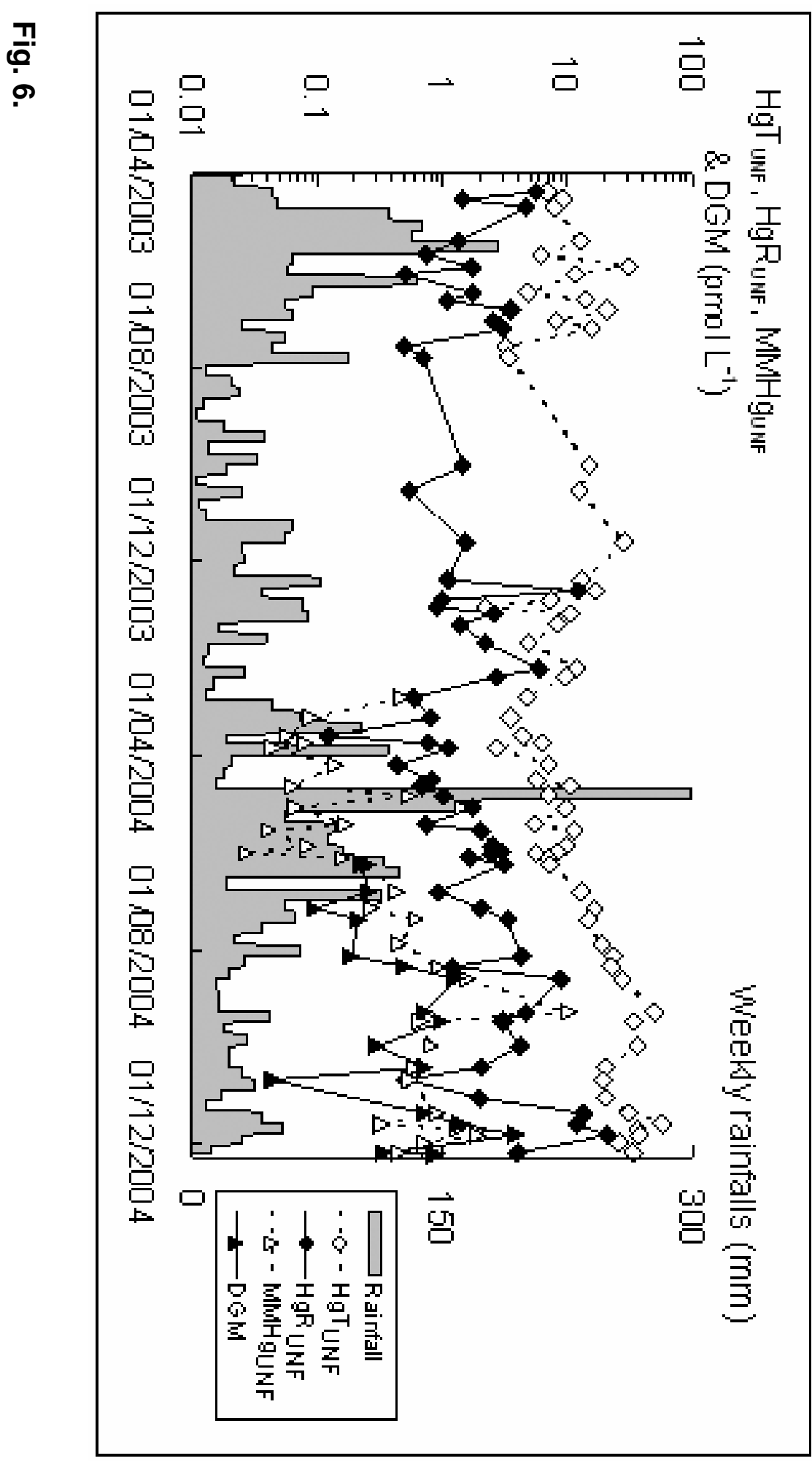

Figure 6. Monitoring of total $\left(\mathrm{HgT}_{\mathrm{UNF}}\right)$, reactive $\left(\mathrm{HgR}_{\mathrm{UNF}}\right)$ and monomethyl $\left(\mathrm{MMHg}_{\mathrm{UNF}}\right)$ concentrations in rain. Wet deposition was collected on a weekly basis at the HYDRECO field laboratory station circa $200 \mathrm{~m}$ downstream of the dam. Shaded motif account for the cumulated quantity of rain fallen every week. 


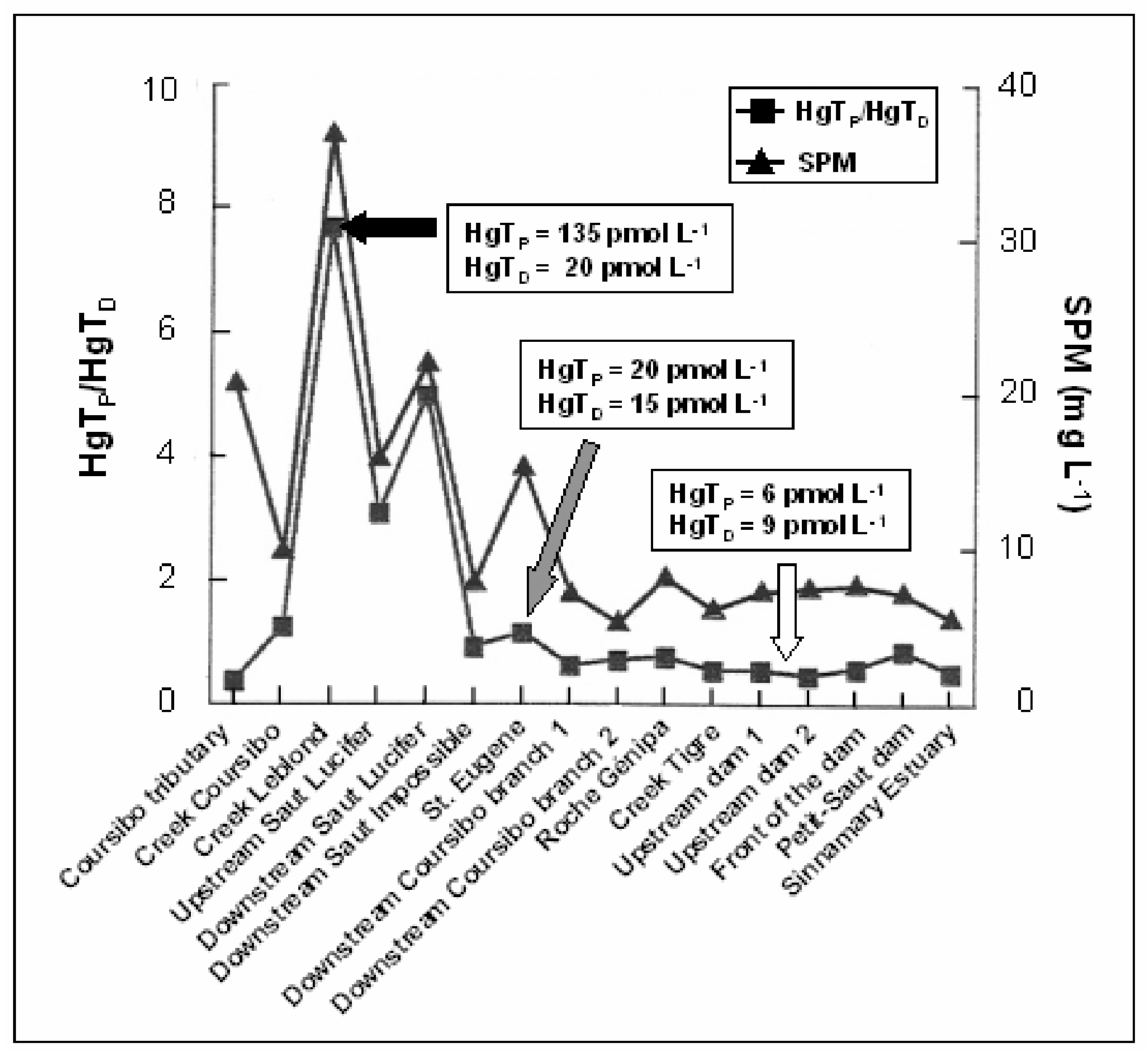

Fig. 7.

Figure 7. Evolution of particulate to dissolved fraction of total mercury $\left(\mathrm{Hg}_{\mathrm{p}} / \mathrm{Hg} \mathrm{T}_{\mathrm{D}}\right)$ between the upstream Coursibo and Leblond tributaries (gold-mining area of Saint Elie) and the Sinnamary Estuary (December 1999). 


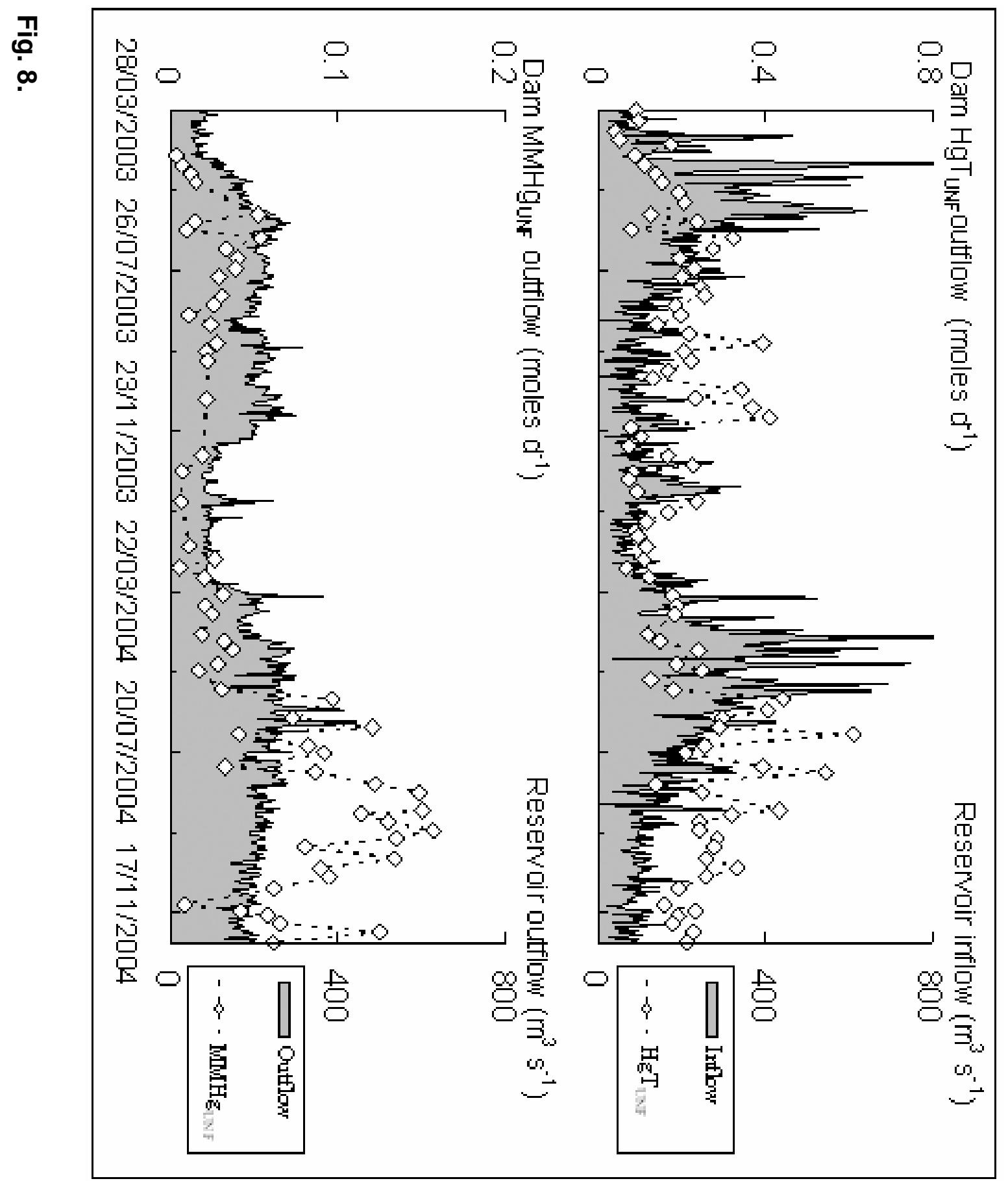

Figure 8. Monitoring of unfiltered total ( $\left.\mathrm{HgT}_{\mathrm{UNF}}\right)$ and monomethyl (MMHgunF) mercury exportation fluxes (moles $\mathrm{d}^{-1}$ ) downstream of the dam (CS station). Water in/outputs to/from the reservoir were recorded daily (HYDRECO data). Samples for $\mathrm{Hg}$ analyses were collected on a weekly basis. 


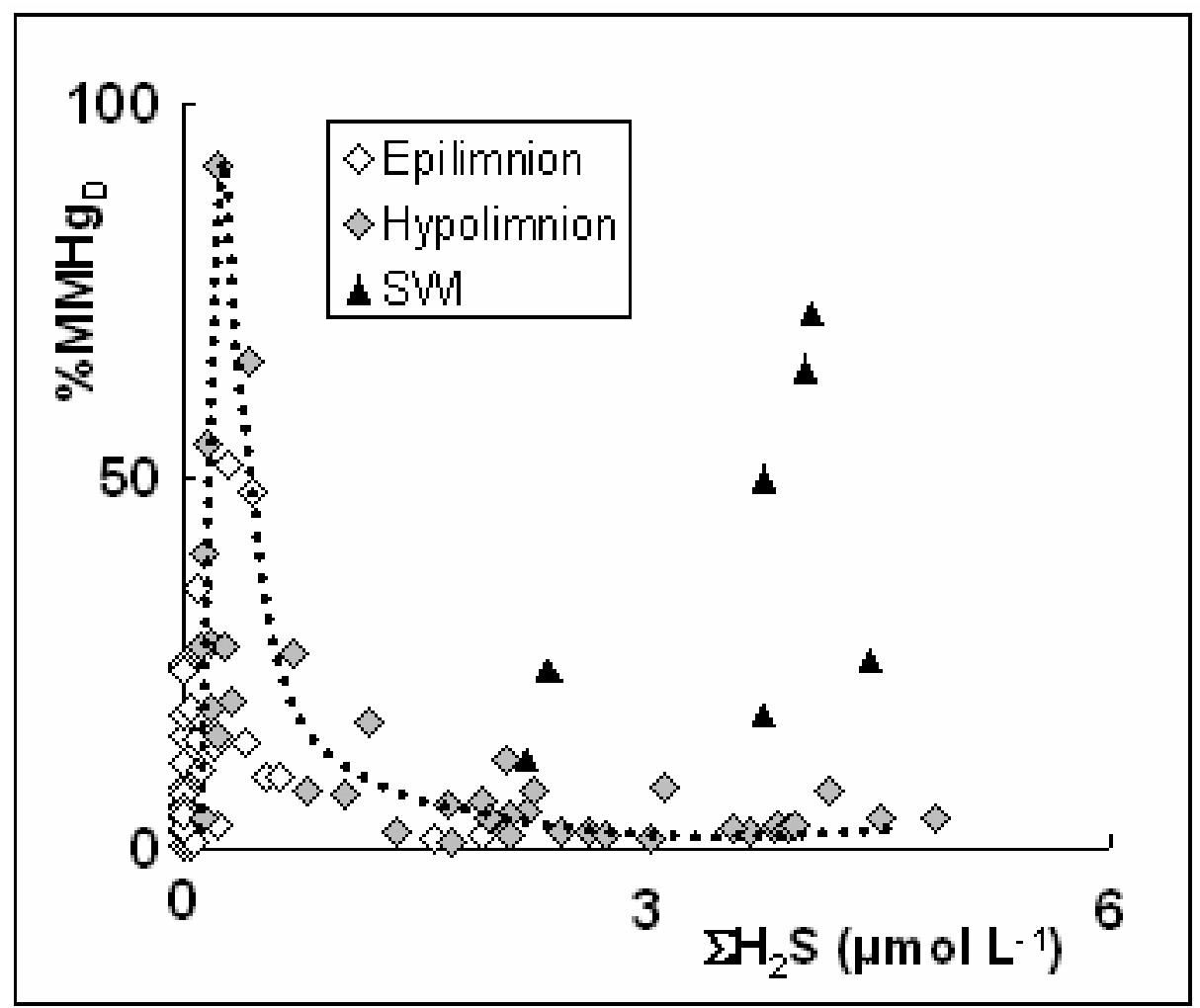

Fig. 9.

Figure 9. Relationship between dissolved methylated percentage (\%MMHg$)$ and total sulfides $\left(\Sigma \mathrm{H}_{2} \mathrm{~S}\right)$ in the water column of the reservoir. Differentiation was made between samples that were collected into the epilimnion (open diamonds), the hypolimnion (filled diamonds) and at the SWI (bold triangles). 


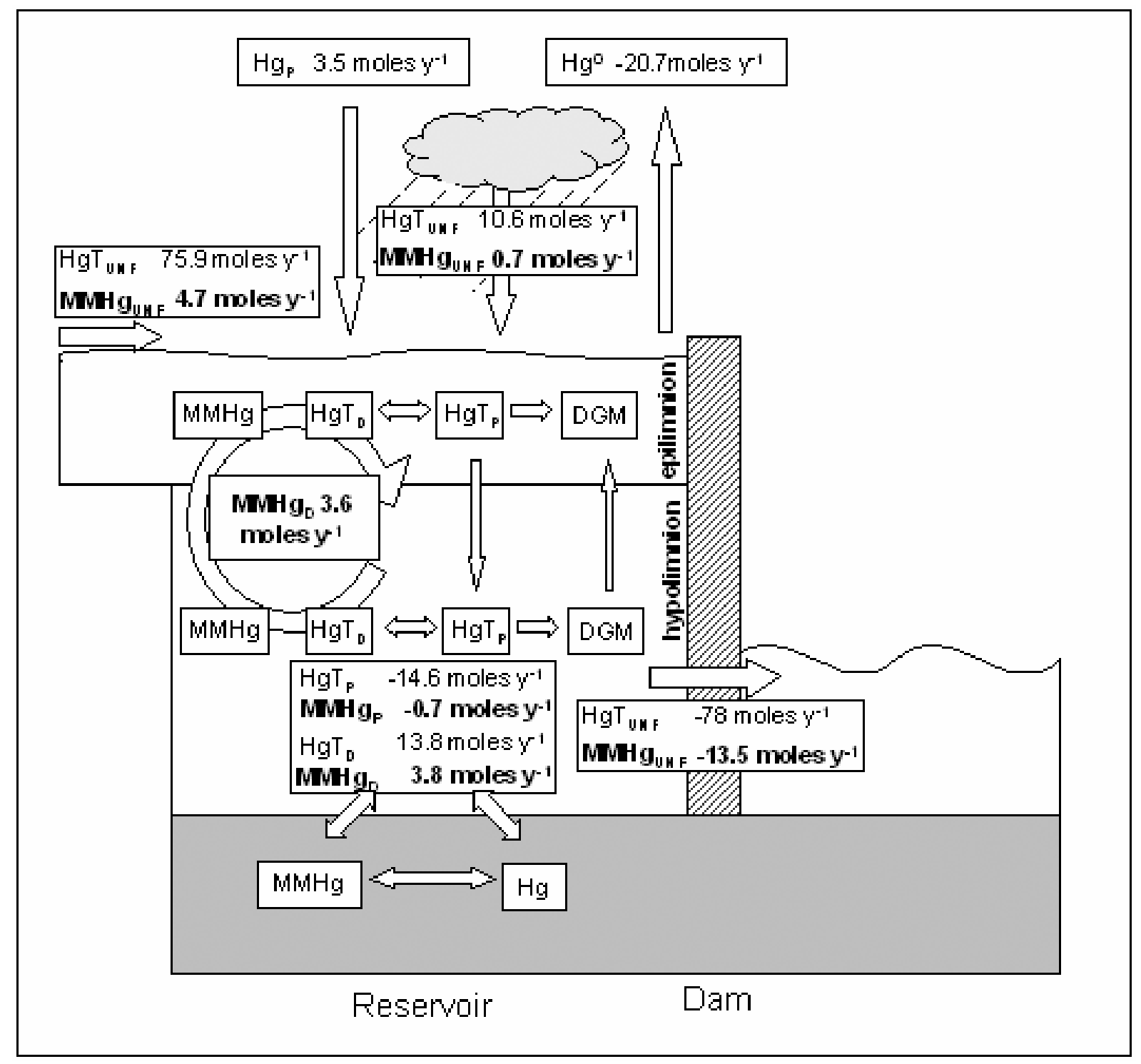

Fig. 10.

Figure 10. $\mathrm{HgT}_{\mathrm{UNF}}$ and $\mathrm{MMHg}_{\mathrm{UNF}}$ budget for the Petit-Saut reservoir. Flux calculations corresponded to the Matoutou 1 to 3 campaigns. Thus, the mass balance estimation only provides indicative data on a particular state of the reservoir on a seasonal time scale. 